L総説

\title{
含フッ素オレフインの反応
}

村 松 広 重*·犬 飼鑑*

Reactions of Fluoroolefins.

Hiroshige Muramatsu and Kan Inukai

含フッ素オレフインは通常のオレフインと同様, $\mathrm{C}=\mathrm{C}$ 結合を利用して種々の反応 ${ }^{1)}$ を行なうことができ，有機 フッ素化合物の合成上工業的にも, 学問的にも重要な出 発原料である。たとえば工業的には $\mathrm{CF}_{2}=\mathrm{CF}_{2}, \mathrm{CF}_{2}=\mathrm{CFCl}$, $\mathrm{CF}_{3} \mathrm{CF}=\mathrm{CF}_{2}$ などの単独重合あるいは共重合により, 耐 熱性, 耐薬品性の良好な合成樹脂, 合成ゴムが得られ, たテロメル化によって含フッ素グリース, オイルが得ら れている。オレフインの構造によっては他の有機物, た とえば八ロゲン化炭化水素, アルコール, アルデヒドな どとラジカル付加反応を行なわせて主として 1:1 付加 物のみをつくることもでき，これはまた他の有用な単量 体をつくる原料となる。これら含フッ素高分子 ${ }^{2}$, テロ メル化 ${ }^{3)}$, ラジカル反応一般(4)についてはすでに本誌に 総説が発表されているので今回は触れず，その後の発展 については機会を改めて述べたいと思う。

含フッ素オレフインはあらゆる原子の中で電気陰性度 のもっとも大きなフッ素原子が水素原子の代りに入って いるため, 含フッ素オレフインに特徽的な反応が存在す る。その 1 つは求核付加反応 (nucleophilic addition) であり，他は環化反応 (cycloaddition) である。ここで はこの両者についてのみ記述することとする。

\section{I. 求核付加反応}

含フッ素オレフインは前記のように電気陰性度の大き なフッ素原子の電子吸引効果のため, 二重結合の電子密 度が通常のオレフインに比べて小さい。それ故, HX, HO $\mathrm{X}, \mathrm{X}_{2}(\mathrm{X}=\mathrm{Cl}, \mathrm{Br}, \mathrm{I})$ などの求電子付加反応がより 困難と なり, 逆に求核付加反応がより容易におこるようになる。 求核試薬としては種々のものが用いられており，C, N, $\mathrm{O}, \mathrm{S}, \mathrm{F}$. などを含む分子またはそのアニオンの付加が発

* 名古屋工業技術試験所（名古屋市北区平手町）
表されている。この反応を利用して多数の有機フッ素化 合物が合成されているが, 以下求核試薬の付加によって 新らしく生成する $\mathrm{C}-\mathrm{C}, \mathrm{C}-\mathrm{O}, \mathrm{C}-\mathrm{N}$ などの結合様式にし たがって反応を分類, 説明する。

1. C-O 結合の生成 1946 年 Hanford $ら^{5}$ が塩基 触媒の存在下で含フッ素オレフィンとアルコールとの付 加反応により含フッ素エーテルを合成して以来, 現在ま で本反応について多数の研究が報告されている。特に含 フッ素ビニルエーテルは重合により得られるポリマーに 而熱性が期待されるため, このの応を利用して含フッ素 ビニルエーテルを合成する試みも行なわれている。一般 的に反応はきわめて容易にすすみ，収率も良好である。 アルコールに水酸化カリウムなどの塩基触媒を添加し, この中に含フッ素オレフィンを導入するか（オレフィン が室温で気体の場合)，あるいは滴下すれば発熱して円 滑に反応していく。たとえば

$\mathrm{CF}_{2}=\mathrm{CF}_{2}+\mathrm{CH}_{3} \mathrm{OH} \stackrel{\mathrm{KOH}}{\longrightarrow} \mathrm{CHF}_{2} \mathrm{CF}_{2} \mathrm{OCH}_{3}$

含フッ素エチレン,$\quad \mathrm{CF}_{2}=\mathrm{CXY}(\mathrm{X}, \mathrm{Y}=\mathrm{H}, \mathrm{F}, \mathrm{Cl}, \mathrm{Br})$ への付加反応ではアルコキシ基はかならず $=\mathrm{CF}_{2}$ 側に付 加する。本反応の機構は〔2〕式のように考えられ6), $=\mathrm{CF}_{2}$ 側をアルコキシイオンが攻撃するのは〔2〕式の矢 印のような共鳴により $\mathrm{CF}_{2}$ の炭素の方が、電子密度が小 となるためといわれている。

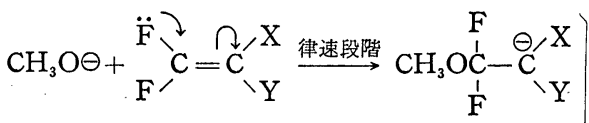

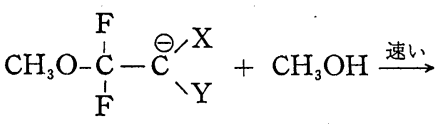

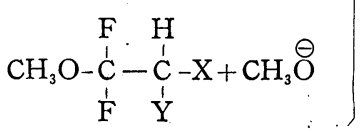


含フッ素エチレンとしては $\mathrm{CF}_{2}=\mathrm{CF}_{2}{ }^{7)}, \mathrm{CF}_{2}=\mathrm{CFCl}^{8)}$, $\left.\mathrm{CF}_{2}=\mathrm{CFBr}^{9)}, \mathrm{CF}_{2}=\mathrm{CCl}_{2}{ }^{9}, \mathrm{CF}_{2}=\mathrm{CHF}^{10}\right), \mathrm{CF}_{2}=\mathrm{CHCl}^{8}$, $\mathrm{CF}_{2}=\mathrm{CHBr}^{11)}, \mathrm{CF}_{2}=\mathrm{CFI}^{11)}$ などが，アルコールとしては 種々の飽和あるいは不飽和の脂肪族アルコール，ジオ一

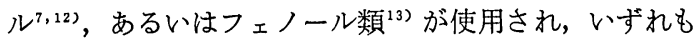
付加反応により対态する含フッ素エーテルを与える。も ちろん反応性は使用する含フッ素エチレンやアルコール の構造によって異なる。

たとえば $\mathrm{CF}_{2}=\mathrm{CCl}_{2}, \mathrm{CF}_{2}=\mathrm{CHCl}$ は $\mathrm{CF}_{2}=\mathrm{CFCl}$ より反 応性にとみ，前者は $t$-ブチルアルコールと常圧下，35〜 $40^{\circ} \mathrm{C}$ で反応するが，後者はこの条件では反応しない。 また脂肪族アルコールの場合, 第一アルコールでは $\mathrm{CHXYCF}_{2} \mathrm{OR}$ のみが得られるが，第二および第三アル

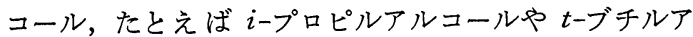
ルコールでは生成するエーテルが不安定で〔3】式のよう にかなりの分解反応を伴なら ${ }^{8)}$ 。

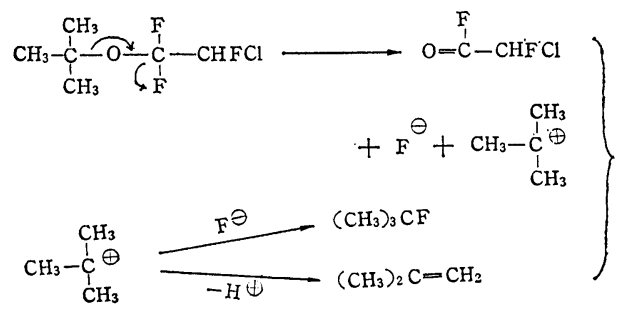

$\mathrm{CF}_{2}=\mathrm{CXY}$ はアルコールとの付加反応で $\mathrm{CHXYCF}_{2} \mathrm{OR}$ の飽和エーテルのみを生成するのに対し, $\mathrm{CF}_{3} \mathrm{CCl}=\mathrm{CCl}_{2}$ 14), $\mathrm{CF}_{3} \mathrm{CCl}=\mathrm{CClCF}_{3}{ }^{15)}$ では同様な条件下で主として $\mathrm{CF}_{3} \mathrm{CCl}=\mathrm{CCl}(\mathrm{OR}), \mathrm{CF}_{3} \mathrm{CCl}=\mathrm{C}(\mathrm{OR}) \mathrm{CF}_{3}$ の不飽和エーテ ルが得られる。そこで Park ら ${ }^{15)}$ は $\mathrm{CF}_{3} \mathrm{CCl}=\mathrm{CFCl}$, $\mathrm{CF}_{3} \mathrm{CCl}=\mathrm{CF}_{2}, \mathrm{CF}_{3} \mathrm{CF}=\mathrm{CCl}_{2}, \mathrm{CF}_{3} \mathrm{CF}=\mathrm{CF}_{2}, \mathrm{CF}_{2} \mathrm{ClCF}=\mathrm{CCl}_{2}$ とアルコールとの付加反応を行ない, $\mathrm{CF}_{3} \mathrm{CHXCX}_{2} \mathrm{OR}$ $(\mathrm{X}=\mathrm{F}, \mathrm{Cl})$ の飽和エーテルを得るには含フッ素プロピレ ンの構造として (1) 生成するエーテルにおいてエーテル 結合の $\alpha$ 位に $\mathrm{CF}_{2}$ 基があるか，(2) 含フッ素プロピレ ンの中央の炭素に F がついていなければならないと報告 している。

$\left(\mathrm{CF}_{3}\right)_{2} \mathrm{C}=\mathrm{CF}_{2}{ }^{16,17)}$ へのアルコールの付加は中性あるい は弱酸性でもすすみ，〔4】式のように飽和エーテルと不 飽和エーテルの両者が生成する。しかし酸性度の強いア

$$
\left.\begin{array}{rl}
\left(\mathrm{CF}_{3}\right)_{2} \mathrm{C}=\mathrm{CF}_{2}+\mathrm{ROH} & \longrightarrow \\
& \left(\mathrm{CF}_{3}\right)_{2} \mathrm{CHCF}_{2} \mathrm{OR} \text { (1) } \\
& \left(\mathrm{CF}_{3}\right)_{2} \mathrm{C}=\mathrm{CFOR} \text { (2) }
\end{array}\right\}
$$

ルコールの場合 $\left(\mathrm{CF}_{3} \mathrm{CH}_{2} \mathrm{OH}\right.$, フェノールなど) には塩 基触媒が存在しないと反応しない。㯰換基のない脂肪族 アルコールでは (1) と（2）が同時に得られ，アルキル基
の炭素鎖が長くなると共に (2) の割合が増加する。また $\mathrm{CH}_{2}=\mathrm{CHCH}_{2} \mathrm{OH}, \mathrm{CH}_{2} \mathrm{ClCH}_{2} \mathrm{OH}$ との付加反応では (2) は得られず， $\left(\mathrm{CF}_{3}\right)_{2} \mathrm{C}=\mathrm{C}(\mathrm{OR})_{2}$ が副生した。 $\left(\mathrm{CF}_{3}\right)_{2} \mathrm{C}=$ $\mathrm{CF}_{2}$ とアルコールとの付加反応における(1),(2) の収率

\begin{tabular}{|c|c|c|}
\hline アル コール & (1) 収率 (\%) & (2) 収率 $(\%)$ \\
\hline $\mathrm{CH}_{8} \mathrm{OH}$ & 70 & 0 \\
\hline $\mathrm{C}_{2} \mathrm{H}_{5} \mathrm{OH}$ & 59 & 6 \\
\hline$n-\mathrm{C}_{8} \mathrm{H}_{7} \mathrm{OH}$ & 43 & 14 \\
\hline$i-\mathrm{C}_{8} \mathrm{H}_{7} \mathrm{OH}$ & 35 & 26 \\
\hline$n-\mathrm{C}_{4} \mathrm{H}_{8} \mathrm{OH}$ & 52 & 27 \\
\hline $\mathrm{CH}_{2}=\mathrm{CHCH}_{2} \mathrm{OH}$ & 56 & 0 \\
\hline $\mathrm{CH}_{2} \mathrm{ClCH}_{2} \mathrm{OH}$ & 51 & 0 \\
\hline $\mathrm{CH}_{2} \mathrm{FCH}_{2} \mathrm{OH}$ & 60 & \\
\hline
\end{tabular}
を表 1 に示す。

表 $1\left(\mathrm{CF}_{8}\right)_{2}=\mathrm{CF}_{2}$ ととアルコールとの反応

ペルフルオル-1,3-ジェンへのアルコールの付加 では 塩基の種類により生成物が異なる ${ }^{18,19)}$ 。

$\mathrm{CF}_{2}=\mathrm{CF}-\mathrm{CF}=\mathrm{CF}_{2}+\mathrm{EtOH}$



含フッ素オレフィンとしては前記以外に $\mathrm{CF}_{2}=\mathrm{CXCN}$ 20,25) $(\mathrm{X}=\mathrm{F}, \mathrm{Cl}), \mathrm{CF}_{3}\left(\mathrm{CF}_{2}\right)_{4} \mathrm{CF}=\mathrm{CF}_{2}{ }^{21)}$ なども報告されて いる。

含フッ素環状オレフィンについてもアルコールとの付 加反応が試みられたが，いずれも飽和エーテルは得られ ず，不飽和エーテルのみが生成した。
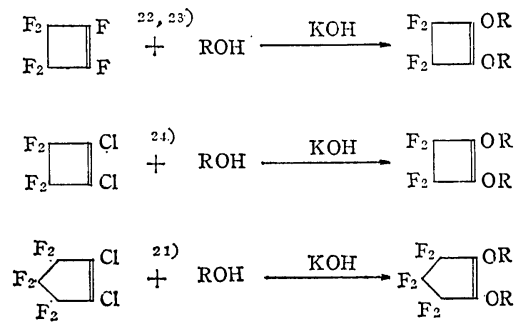

[7],[8]式の場合，過剩のアルコール，塩基とさらに反 応させると, モノエーテルと共に (3) のようなトリエー テルが生成した。この生成機構は〔9]式のように推定さ れている.'11。




前記のように含フッ素エチレンとアルコールとを塩基 の存在下で反応させると飽和エーテルのみが生成する が, アルコラート ${ }^{26288}$ をエーテル，ジオキサン中で反 応させると含フッ素ビニルエーテルが得られ，これらは 重合してポリマーを与える。

$$
\mathrm{CF}_{2}=\mathrm{CFX}+\mathrm{RO} \ominus \longrightarrow \underset{\mathrm{F}}{\mathrm{ROCF}-\mathrm{CFX}}
$$$$
\stackrel{\mathrm{Na} \oplus}{\longrightarrow} \mathrm{ROCF}=\mathrm{CFX}+\mathrm{NaF}(\mathrm{X}=\mathrm{F}, \mathrm{Cl})
$$

アルコールの付加に類似のものとして，含フッ素オレ フィンとオキシムとの反応 $\left.{ }^{29}, 30\right)$ があり, 含フッ素 $O$-ア ルキルオキシムが得られる。また過酸化水素を塩基の存 在下でペルフルオルオレフィンに反応 ${ }^{31}$ させて, 対応す る含フッ素エポキシドを得ている。

$$
\mathrm{CF}_{2}=\mathrm{CXY}+\mathrm{R}_{2} \mathrm{C}=\mathrm{NOH} \longrightarrow
$$$$
\mathrm{CHXYCF}_{2} \mathrm{ON}=\mathrm{CR}_{2}
$$

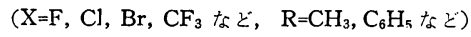

2. $\mathbf{C}-\mathrm{N}$ 結合の生成 $\mathrm{CF}_{2}=\mathrm{CF}_{2}$ を酢酸銅の存在下 でアンモニアガスと室温で反応させると発熱して2, 4, 6トリス (ジフルオルメチル)-sートリアジンを生成する゙。 本反忘は中間にジフルオルアセトニトリルが生成し，こ れがただちに環化すると考えられている。

$$
\begin{aligned}
& \mathrm{CF}_{2}=\mathrm{CF}_{2}+\mathrm{NH}_{3} \longrightarrow\left[\mathrm{CHF}_{2} \mathrm{CN}\right]+2 \mathrm{HF}
\end{aligned}
$$

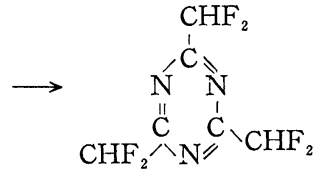

乙かし $\mathrm{CF}_{2}=\mathrm{CCl}_{2}, \mathrm{CF}_{3} \mathrm{CF}=\mathrm{CF}_{2}, \mathrm{C}_{2} \mathrm{~F}_{5} \mathrm{CF}=\mathrm{CF}_{2},\left(\mathrm{CF}_{3}\right)_{2} \mathrm{C}=$ $\mathrm{CF}_{2}, \mathrm{CF}_{3}\left(\mathrm{CF}_{2}\right)_{6} \mathrm{CF}=\mathrm{CF}_{2}$ などからは対応する含フッ素ニ

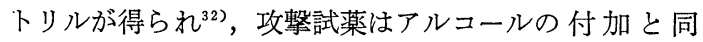
様, $=\mathrm{CF}_{2}$ 側の炭素を攻撃する。一般に酸素や窒素に対 $\mathrm{CF}_{3} \mathrm{CF}_{2} \mathrm{CF}=\mathrm{CF}_{2} \stackrel{\mathrm{NH}_{3}}{\longrightarrow} \mathrm{CF}_{3} \mathrm{CF}_{2} \mathrm{CHFCN}+2 \mathrm{HF} \cdots[13]$ しょ位の炭素についたフッ素は非常に不安定でただちに "脱 $\mathrm{HF}$ し，現在まで多くの試みにもかかわらず $\mathrm{R}_{\mathrm{f}} \mathrm{CF}_{2}$ $\mathrm{OH}, \mathrm{R}_{\mathrm{f}} \mathrm{CF}_{2} \mathrm{NH}_{2}$ 型の化合物は単離されていない。

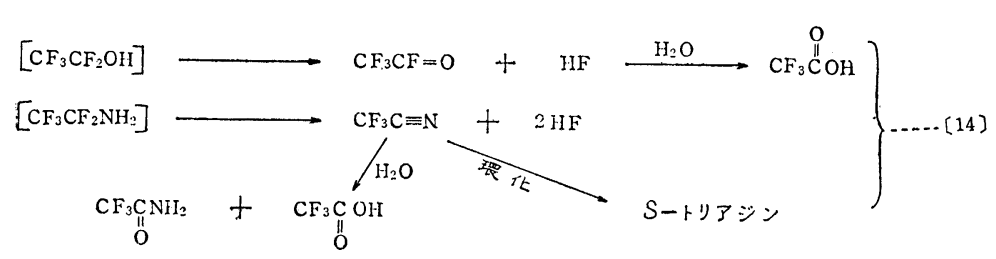

それゆえ〔12〕,〔13】式の場合もまず二重結合に $\mathrm{NH}_{3}$ 功付加して中間に不安定な $\mathrm{R}_{\mathrm{f}} \mathrm{CHFCF}_{2} \mathrm{NH}_{2}$ の一級アミ ンが生成し，これがただちに脱 HFしてニトリルになっ たものと考えられる。ここで得られた含フッ素ニトリル
をさらにアンモニアと反応させるとアミジンとなり，こ れを加熱すれば $s$-トリアジン環が生成する ${ }^{33)}$ 。

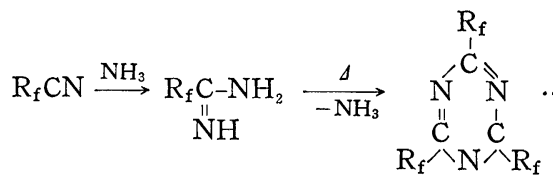

$\mathrm{CF}_{2} \mathrm{ClCF}=\mathrm{CF}_{2}, \mathrm{CF}_{2} \mathrm{ClCCl}=\mathrm{CF}_{2}$ とアンモニアをベンゼ ンまたはジオキサン中で $0 \sim 100^{\circ} \mathrm{C}$ に加熱すると不飽和 のニトリル, $\mathrm{CF}_{2}=\mathrm{CFCN}, \mathrm{CF}_{2}=\mathrm{CClCN}$ がそれぞれ得ら れた。 ${ }^{34}$

ホウ砂の存在下で $\mathrm{CF}_{2}=\mathrm{CF}_{2}$ とアミンとを反応させる と中間に不安定な $N$-置換 $\alpha, \alpha, \beta, \beta$-テトラフルオルア ミンを経て $N$-置換ジフルオルアセトアミドを生成す る7)。

$$
\begin{aligned}
\mathrm{CF}_{2}=\mathrm{CF}_{2}+\mathrm{RNH}_{2} & \longrightarrow\left[\mathrm{CHF}_{2} \mathrm{CF}_{2} \mathrm{NHR}\right] \\
& \stackrel{\mathrm{H}_{2} \mathrm{O}}{\longrightarrow} \mathrm{CHF}_{2} \mathrm{CONHR} \ldots \ldots \ldots \ldots
\end{aligned}
$$

脂肪族あるいは芳香族の一級アミンを温和な条件で， $\mathrm{CF}_{2}=\mathrm{CFCl}$ と触媒なしで反応させると，中間に不安定な 付加物 (4)を経てイミド (5) とアミジン (6) が得られ $ろ^{7,35,36)}$ 。

イミドは加水分解すると対応する酸アミドとなる。芳 香族アミンは脂肪族アミンと同様に反応するが反応速度 はもっと遅い。

$$
\mathrm{CF}_{2}=\mathrm{CFCl}+\mathrm{RNH}_{2} \longrightarrow
$$

$$
\begin{aligned}
& \mathrm{CHClFCF}_{2} \mathrm{NHR} \text { (4) } \stackrel{-\mathrm{HF}}{\longrightarrow} \\
& \underbrace{\mathrm{CHFClCF}=\mathrm{NR}}_{\text {RNHF }_{F_{2}}}(\overline{5})-\mathrm{CHFCIC}_{-{ }_{\mathrm{NHR}}}^{\mathrm{NRR}}
\end{aligned}
$$

二級アミンと $\mathrm{CF}_{2}=\mathrm{CFCl}$ との反応ではまゔ $1: 1$ 付加 物 (7) が得られるが，過制のアミンにより付加と脱 HX を繰返して最終的にはテトラキスー(ジ アルキルアミノ)エチレン (8) となる。

$$
\begin{aligned}
& \mathrm{CF}_{2}=\mathrm{CFCl}+\mathrm{R}_{2} \mathrm{NH} \longrightarrow \\
& \mathrm{CHFClCF}_{2} \mathrm{NR}_{2}(7) \stackrel{-\mathrm{HF}}{\longrightarrow} \\
& \mathrm{CFCl}=\mathrm{CFNR}_{2} \frac{1) \mathrm{R}_{2} \mathrm{NH}}{2)-\mathrm{HF}} \longrightarrow \\
& \mathrm{R}_{2} \mathrm{~N}_{\backslash} \mathrm{C}^{\prime}=\mathrm{C}_{\backslash}^{\prime} \mathrm{NR}_{2}
\end{aligned}
$$

脂肪族第二アミンが $\mathrm{CF}_{2}=\mathrm{CXY}$ の含フッ素オレフィンに 付加反応した場合 ${ }^{37)}$ の生成物, 飽和アミンと不飽和アミ 
ン（エナミン）との割合は，表 2 に示したようにオレフ インの構造によって異なる。芳香族の第二アミン，たと

表 $2 \mathrm{CF}_{2}=\mathrm{CXY}$ と第二アミンとの反応

\begin{tabular}{|c|c|c|}
\hline \multirow{2}{*}{$\begin{array}{c}\text { 含フッ倠オレフィン } \\
\mathrm{CF}_{2}=\mathrm{CXY}\end{array}$} & 生 & 物 (\%) \\
\hline & $\mathrm{CHXYCF}{ }_{2} \mathrm{NR}_{2}$ & $\mathrm{CXY}=\mathrm{CFNR}_{2}$ \\
\hline $\mathrm{X}=\mathrm{F}, \mathrm{Y}=\mathrm{F}$ & 100 & 0 \\
\hline $\mathrm{X}=\mathrm{F}, \mathrm{Y}=\mathrm{CF}_{\mathrm{s}}$ & 70 & 30 \\
\hline $\mathrm{X}=\mathrm{CF}_{8}, \mathrm{Y}=\mathrm{CF}_{8}$ & 0 & 100 \\
\hline
\end{tabular}

えばジフェニルアミンは反応性が弱く, 加熱しても付加 しない。

ペルフルオルシクロブテンと脂肪族第一アミンとの反 応ではイミノ化合物 (9) が得られ，〔19〕式のような機 構が提案 ${ }^{36)}$ れている。

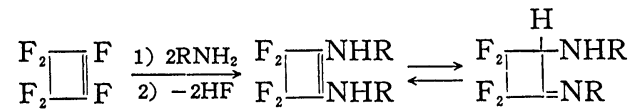

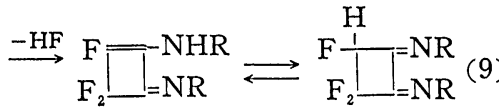

また第二アミンとの反応ではエナミンが生成する ${ }^{36)}$ 。

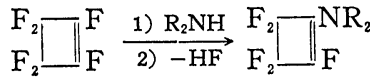

Knunyants らは $\mathrm{CF}_{2}=\mathrm{CF}-\mathrm{CF}=\mathrm{CF}_{2}{ }^{38)}, \mathrm{CF}_{2}=\mathrm{CFCN}^{39)},(\mathrm{C}$ $\left.\mathrm{F}_{3}\right)_{2} \mathrm{C}=\mathrm{CF}_{2}{ }^{17)}, \mathrm{CF}_{3} \mathrm{CF}=\mathrm{CF}_{2}{ }^{17)}$ などと第一および第二アミ ンとをエーテル中で付加反応させて次のような生成物を 得ている。[21]式におけるように反忘は1,2-付加である。 $\mathrm{CF}_{2}=\mathrm{CFCF}=\mathrm{CF}_{2}+\mathrm{Et}_{2} \mathrm{NH} \longrightarrow$

$$
\begin{gathered}
\mathrm{CF}_{2}=\mathrm{CFCF}=\mathrm{CFN}(\mathrm{Et})_{2} \stackrel{\mathrm{H}_{2} \mathrm{O}}{\longrightarrow} \\
\mathrm{CF}_{2}=\mathrm{CFCHFCN}(\mathrm{Et})_{2} \cdots
\end{gathered}
$$

$$
\mathrm{CF}_{2}=\mathrm{CFCN}+\mathrm{PhNH}_{2} \stackrel{\mathrm{H}_{2} \mathrm{O}}{\longrightarrow} \underset{\mathrm{O}}{\mathrm{PhNHCCHFCN} \cdots[22]}
$$

$\mathrm{CF}_{2}=\mathrm{CX}_{2}\left(\mathrm{X}=\mathrm{F}, \mathrm{Cl}, \mathrm{H}, \mathrm{CF}_{3}\right.$ など)とピロール,インドー ル，1,4-ジヒドロピリジンなどとをジメチルホルムアミ

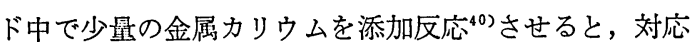
する $N$-フルオルアルキル化合物が得られる。酸アミド 類 ${ }^{30)}$ 少量のアルカリ金属の添加によりジオキサン中で 含フッ秦オレフィンに付加する。

$$
\begin{aligned}
& \mathrm{CF}_{2}=\mathrm{CFCl}+\longrightarrow-\mathrm{NHCOCH}_{3} \stackrel{\mathrm{Na}}{\longrightarrow} \\
& \mathrm{CF}_{2} \mathrm{CHFCl} \\
& -\mathrm{N}-\mathrm{COCH}_{3}
\end{aligned}
$$

含フッ素オレフィンとヒドラジン (水和物) ${ }^{41)}$ とをア ルコール類の溶媒中, $100^{\circ} \mathrm{C}$ 以下で反応させると 1,2 ジヒドロ-3,6-ビスー(フルオルアルキル)-s-テトラジン
（10）が得られ，これを濃硝酸で酸化すると対応するテ トラジン（11）となる。もしエーテル，ジオキサン中で 反応させると (10) の代りに $\alpha$-フルオルヒドラン゙ン (12) が得られ，これは室温で数日間放置するか，加熱または 鈗酸で処理すると（10）に変化する。

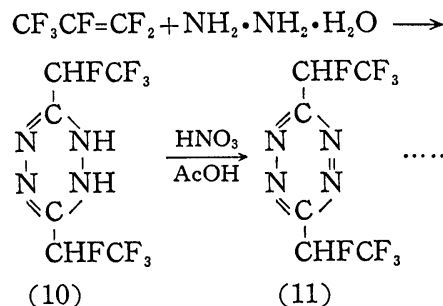

$\mathrm{CF}_{3} \mathrm{CF}=\mathrm{CF}_{2}+\mathrm{NH}_{2} \cdot \mathrm{NH}_{2} \longrightarrow$

$\mathrm{CF}_{3} \mathrm{CHFCF}=\mathrm{N} \cdot \mathrm{NH}_{2}(12)$

フェニルヒドラジン ${ }^{41)}$, セミカルバジッド ${ }^{41)}$ ，ヒドロキ


ニルヒドラゾン， $\alpha$-フルオルセミカルバゾン， $\alpha$-フルオ ルオキシムをそれぞれ生成する。

$$
\left.\begin{array}{c}
\mathrm{CF}_{3} \mathrm{CF}=\mathrm{CF}_{2}+\mathrm{NH}_{2} \cdot \mathrm{NHR} \longrightarrow \\
\mathrm{CF}_{3} \mathrm{CFHCF}=\mathrm{N} \cdot \mathrm{NHR} \\
\left(\mathrm{R}=\mathrm{C}_{6} \mathrm{H}_{5}, \mathrm{CONH} \mathrm{CON}_{2}\right) \\
\mathrm{CF}_{3} \mathrm{CF}=\mathrm{CF}_{2}+\mathrm{NH}_{2} \mathrm{OH} \underset{\mathrm{MeOH}}{\longrightarrow} \\
\mathrm{CF}_{3} \mathrm{CFHCF}=\mathrm{N} \cdot \mathrm{OH} \cdot \mathrm{MeOH} \\
\left.\mathrm{CF}_{3} \mathrm{CF}=\mathrm{CF}_{2}+\mathrm{NH}_{2} \mathrm{OH} \underset{\mathrm{Et}_{2} \mathrm{O}}{(\mathrm{CF}} \cdot \mathrm{CFHCF}=\mathrm{N} \cdot \mathrm{OH}\right)_{2} \cdot \mathrm{EtOH}
\end{array}\right)
$$

$\mathrm{HN}_{3}{ }^{43)}, \mathrm{NaN}_{3}{ }^{44)}$ との反応では，対応する含フッ素アル キルアジド化合物が得られる。

このほか, 含フッ素オレフィンとニトロソ化合物との 付加により C-N 結合が生成するが，これについては後 で簡単に述べる。

\section{C-C 結合の生成}

i. シアン化アルカリ ${ }^{45)}$ 含フッ素オレフィンヘの求 核付加反応による C-C 結合生成の一つに シアンイオン の付加がある。通常の脂肪族化合物ではニトリルを合成 するのにハロゲン化アルキルとシアン化アルカリとの求 核置換反応が利用されるが，含フッ素アルキルニトリル は塩基の存在下では非常に不安定で容易に加水分解され て, 対応するカルボン酸と酸アミドになる。 $\mathrm{CF}_{2}=\mathrm{CF}_{2}$, $\mathrm{CF}_{2}=\mathrm{CFCl}, \mathrm{CF}_{2}=\mathrm{CCl}_{2}, \mathrm{CF}_{2}=\mathrm{CFBr}$ などの含フッ素オレフ ィンとシアン化ナトリウム水溶液とをアセトニトリル中 で反応させると発熱して，対応する含フッ素プロピオン 酸とそのアミドが約 $3: 1$ の割合で生成し，その収率は 40〜90\% である。 


$$
\begin{aligned}
& \mathrm{CX}_{2}=\mathrm{CF}_{2}+\stackrel{\ominus}{\mathrm{C} N} \longrightarrow\left(\begin{array}{c}
\mathrm{X} \\
1 \\
\ominus \\
\stackrel{\ominus}{C}-\mathrm{CF}_{2} \mathrm{CN} \\
\mathrm{X}
\end{array}\right) \stackrel{\mathrm{H}_{2} \mathrm{O}}{\longrightarrow} \\
& {\left[\mathrm{CHX}_{2} \mathrm{CF}_{2} \mathrm{CN}\right]+\stackrel{\ominus}{\mathrm{O}} \mathrm{H} \stackrel{\mathrm{H}_{2} \mathrm{O}}{\longrightarrow} \mathrm{CHX}_{2} \mathrm{CF}_{2} \mathrm{CONH}_{2}} \\
& \stackrel{\mathrm{OH}^{\ominus}}{\longrightarrow} \mathrm{CHX}_{2} \mathrm{CF}_{2} \mathrm{COO} \Theta \\
& \text { ( } \mathrm{X}=\mathrm{F}, \mathrm{Cl}, \mathrm{Br} \text { ) }
\end{aligned}
$$

$\mathrm{CF}_{3} \mathrm{CF}=\mathrm{CF}_{2}, \mathrm{CH}_{3}\left(\mathrm{CH}_{2}\right)_{3} \mathrm{CF}=\mathrm{CF}_{2}$ も高温の条件下で同様 に対応する酸アミドを生成する。溶媒としてジメチルホ ルムアミドを用いた場合は，反応はより急速にすすむが 生成物と Complex をつくり易いので操作が面倒となる。

ii. グリニヤール試薬 ${ }^{46)}$ グリニヤール試薬は含フッ 素オレフインと〔28]式のように反応する。アルキル基

$\mathrm{C}_{2} \mathrm{H}_{5} \mathrm{MgBr}+\mathrm{CF}_{2}=\mathrm{CCl}_{2} \longrightarrow \mathrm{C}_{2} \mathrm{H}_{5} \mathrm{CF}=\mathrm{CCl}_{2}$

$$
\mathrm{C}_{6} \mathrm{H}_{5} \mathrm{MgBr}+\mathrm{CF}_{2}=\mathrm{CFCl} \longrightarrow \mathrm{C}_{6} \mathrm{H}_{5} \mathrm{CF}=\mathrm{CFCl}
$$

およびフェニル基の付加の方向は 1.2. の場合と同じく フッ素の数が多い方の炭素を攻撃するが中間に生成した $\mathrm{RCF}_{2} \mathrm{C}-\mathrm{X}_{2} \mathrm{MgBr}$ から $\mathrm{MgFBr}$ がただちに脱離し， $\mathrm{RCF}=$ $\mathrm{CX}_{2}$ となる。飽和の付加物 $\mathrm{RCF}_{2} \mathrm{CHX}_{2}$ は得られていな い。 $\mathrm{CF}_{2} \mathrm{ClCF}=\mathrm{CF}_{2}, \mathrm{CF}_{2} \mathrm{BrCF}=\mathrm{CF}_{2}$ と $\mathrm{PhMgBr}$ との反応 の場合，(13) (14) の 2 種が同時に得られるが， $\mathrm{CF}_{2} \mathrm{Cl}$ $\mathrm{CF}=\mathrm{CF}_{2}$ では (13) が (14) の 4 倍, $\mathrm{CF}_{2} \mathrm{BrCF}=\mathrm{CF}_{2}$ では ほとんど（14）のみが生成した。

$$
\begin{aligned}
& \mathrm{PhMgBr}+\mathrm{CF}_{2}=\mathrm{CFCF}_{2} \mathrm{X} \longrightarrow
\end{aligned}
$$

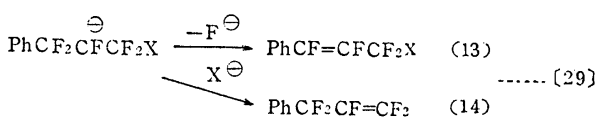

$$
\begin{aligned}
& (X=F, C l)
\end{aligned}
$$

一般に芳香族グリニヤール試薬との反応は脂肪族の場合 より収率が良い。たとえば $\mathrm{CF}_{2}=\mathrm{CCl}_{2}$ との反応では $\mathrm{Ph}$ $\mathrm{MgBr}$ からは $64 \%$ の收率で $\mathrm{PhCF}=\mathrm{CCl}_{2}$ が得られた が, $\mathrm{C}_{2} \mathrm{H}_{5} \mathrm{MgBr}$ からは $\mathrm{C}_{2} \mathrm{H}_{5} \mathrm{CF}=\mathrm{CCl}_{2}$ が $10 \%$ 生成した にすぎない。

$\mathrm{RMgBr}$ において $\mathrm{R}$ の構造により反応性が異なり，反 応性は $\mathrm{CH}_{3}>\mathrm{C}_{2} \mathrm{H}_{5}>\left(\mathrm{CH}_{3}\right)_{2} \mathrm{CH}$ の順に減少した。また 置換基をもつ $\mathrm{PhMgBr}$ で崔電子吸引性の置換基の存在 は反応を遅らせる。 $\mathrm{CFH}=\mathrm{CHCl}, \mathrm{CF}_{2}=\mathrm{CHCl}, \mathrm{CF}_{2}=\mathrm{CH}_{2}$ な どの場合には対応する生成物が得られなかった。

iii. 有機リチウム化合物 ${ }^{47,48}$ ) 有機リチウム化合物 はグリニヤール試薬よりもさらに収率が良く，数多くの 含フッ素オレフィンとの反応が行なわれている。 $\mathrm{CF}_{2}=$ $\mathrm{CF}_{2}$ と $\mathrm{PhLi}$ とをエーテル中で低温で反応させると通常 $\mathrm{PhCF}=\mathrm{CFPh}$ が得られる。しかし過剩のオレフィンを使 用すると $\mathrm{PhCF}=\mathrm{CF}_{2}$ が，逆に $\mathrm{PhLi}$ を過剩にするか，反 応温度を高くするとオレフィン上のフッ素が順次フェニ
ル基で置換して，最終的には $\mathrm{C}(\mathrm{Ph})_{2}=\mathrm{C}(\mathrm{Ph})_{2}$ となる。 非対称の含フッ素オレフィン $\mathrm{CF}_{2}=\mathrm{CX}_{2}$ との反応では主 として $\mathrm{PhCF}=\mathrm{CX}_{2}(\mathrm{X}=\mathrm{F}, \mathrm{Cl})$ が得られる。

含フッ素オレフィンの構造として, $\mathrm{CFY}=\mathrm{CX}_{2}$ のYが $\mathrm{F}$ またはペルフルオルアルキル基，Xが電子吸引基であ れば反応する。また $\mathrm{CFCl}=\mathrm{CFOC}_{2} \mathrm{H}_{5}$ と $\mathrm{PhLi}$ との反 応 ${ }^{49}$ では $\mathrm{PhCCl}=\mathrm{CFOC}_{2} \mathrm{H}_{5}, \mathrm{CF}_{2}=\mathrm{CFSi}\left(\mathrm{C}_{2} \mathrm{H}_{5}\right)_{3}$ と $\mathrm{RLi}$ と の反応 ${ }^{50}$ では $\mathrm{RCF}=\mathrm{CFSi}\left(\mathrm{C}_{2} \mathrm{H}_{5}\right)_{3}$ が得られている。

有機リチウム試薬としてはアルキル，アリル，異節環 のリチウム化合物などすべて同様に反応する。代表的な 例を表 3 に示した。

表 3 含フッ素オレフィンとリチウム化合物との反応 ${ }^{47}$

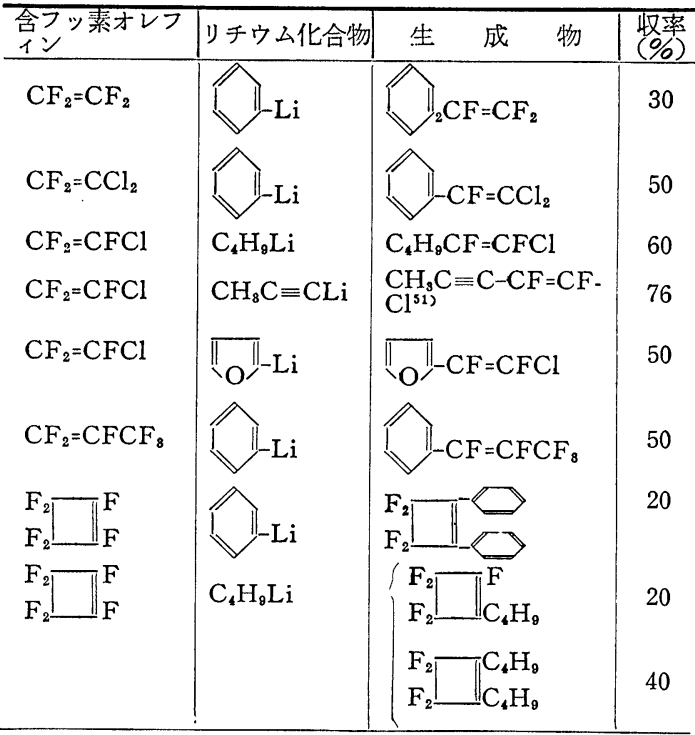

in iv. 有機ナトリウム化合物 ${ }^{302}$ 有機金属化合物とし てナトリウム化合物も用いられるが特殊な場合を除いて 収率は一般に良くない。たとえば

$$
\begin{aligned}
& \mathrm{C}_{4} \mathrm{H}_{9} \mathrm{C} \equiv \mathrm{CNa}+\mathrm{CF}_{2}=\mathrm{CF}_{2} \longrightarrow \\
& \mathrm{C}_{4} \mathrm{H}_{9} \mathrm{C} \equiv \mathrm{C}-\mathrm{CF}=\mathrm{CF}-\mathrm{C} \equiv \mathrm{C}-\mathrm{C}_{4} \mathrm{H}_{9} \\
&(30 \%) \\
& \mathrm{C}_{6} \mathrm{H}_{5} \mathrm{C} \equiv \mathrm{CNa}+\mathrm{CF}_{2}=\mathrm{CF}_{2} \longrightarrow \\
& \mathrm{C}_{6} \mathrm{H}_{5} \mathrm{C} \equiv \mathrm{C}-\mathrm{CF}=\mathrm{CF}-\mathrm{C} \equiv \mathrm{C}-\mathrm{C}_{6} \mathrm{H}_{5} \\
&(9 \%)
\end{aligned}
$$

同様にジフェニルアセトニトリル，マロン酸ジェチルの ナトリウム塩と $\mathrm{CF}_{2}=\mathrm{CF}_{2}$ との反応もジオキサン中で行 なわれている。

$\mathrm{NaCH}\left(\mathrm{CO}_{2} \mathrm{Et}\right)_{2}+\mathrm{CF}_{2}=\mathrm{CF}_{2} \longrightarrow$

$\left(\mathrm{EtO} \mathrm{O}_{2} \mathrm{C}\right)_{2} \mathrm{CHCF}=\mathrm{CFCH}\left(\mathrm{CO}_{2} \mathrm{Et}\right)_{2}$ [31] $(49 \%)$

種々の有機金属化合物の反応性を $\mathrm{CF}_{2}=\mathrm{CFCl}$ との反応 について調べた(例尔を表 4 にあげた。 
表 4 有機金属化合物と $\mathrm{CF}_{2}=\mathrm{CFCl}$ との反応

\begin{tabular}{l|c}
\hline \multicolumn{1}{c|}{ 有機金属化合物 } & 生成オンフィンの収率 $(\%)$ \\
\hline$\left(\mathrm{C}_{6} \mathrm{H}_{5}\right)_{8} \mathrm{CNa}$ & 94 \\
$\mathrm{C}_{6} \mathrm{H}_{5} \mathrm{Li}$ & 91 \\
$\mathrm{C}_{6} \mathrm{H}_{5} \mathrm{CaI}$ & 38 \\
$\mathrm{C}_{6} \mathrm{H}_{5} \mathrm{MgBr}$ & 16.1 \\
$\left(\mathrm{C}_{2} \mathrm{H}_{3}\right)_{8} \mathrm{Al}$ & - \\
\hline
\end{tabular}

4. C-S 結合の生成 $\mathrm{CF}_{2}=\mathrm{CF}_{2}$ と $\mathrm{RSH}$ との塩基 触媒存在下での付加反応が発表 ${ }^{52}$ されて以来，トリエチ ルアミン，ベンジルトリメチルアンモニウムヒドロキシ ド (Triton B) を触媒にして $\mathrm{CF}_{2}=\mathrm{CFCl}, \mathrm{CF}_{2}=\mathrm{CCl}_{2}$, $\mathrm{F}_{2} \amalg \mathrm{F}$ など ${ }^{53}$ にチオール類が付加されている。Knunyants $5^{54)}$ は $\mathrm{CF}_{2}=\mathrm{CF}_{2}, \mathrm{CF}_{2}=\mathrm{CFCl}, \mathrm{CF}_{2}=\mathrm{CCl}_{2}, \mathrm{CF}_{3} \mathrm{CF}=\mathrm{CF}_{2}$ について同様なチオール類の求核付加反応を水酸化カリ ウムを触媒にして行なっている。非対称オレフィンへの$$
\mathrm{CF}_{2}=\mathrm{CFCl}+\mathrm{RSH} \longrightarrow \mathrm{CHFClCF}_{2} \mathrm{SR}
$$

付加の方向はアルコールの場合と同じであり, 反応は室 温で円滑に進行する。 $\mathrm{HOC}_{2} \mathrm{H}_{4} \mathrm{SH}$ のアルカリ触媒存在 下の付加では $\mathrm{CHFClCF}_{2} \mathrm{SC}_{2} \mathrm{H}_{4} \mathrm{OH}$ のみが得られる。

ペルフルオルシクロブテンは $\mathrm{CF}_{2}=\mathrm{CFCl}$ よりもさら に反応性にとみ，(15)，(16)，(17）の生成物が単離され た。〔33〕式の反応機構が提案 ${ }^{53}$ されている。

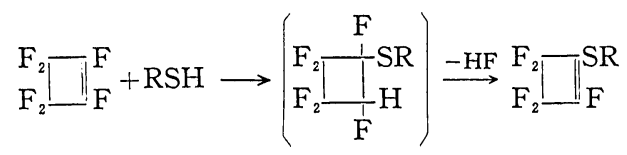

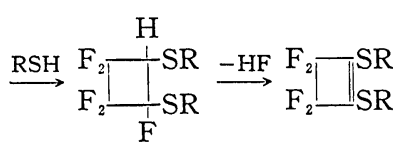

亜硫酸ナトリウムまたは酸性亜硫酸ナトリウムと含フ ッ素オレフインとをホウ砂などの存在下で加熱するとフ ルオルアルカンスルホン酸ナトリウム塩が生成 ${ }^{55}$ する。 その例を 表 5 に示した。

$\mathrm{R}_{\mathrm{f}} \mathrm{CF}=\mathrm{CF}_{2}+\mathrm{NaHSO}_{3} \longrightarrow \mathrm{R}_{\mathrm{f}} \mathrm{CHFCF}_{2} \mathrm{SO}_{3} \mathrm{Na} \cdots[34]$

\begin{tabular}{|c|c|c|c|}
\hline 含フッ素オレフィン & |亜硫酸坮 $\mid$ & 生成スルホン酸 & $\begin{array}{l}4 \text { 率 } \\
(\%)\end{array}$ \\
\hline $\mathrm{CF}_{2}=\mathrm{CF}_{2}$ & $\mathrm{Na}_{2} \mathrm{SO}_{3}$ & $\mathrm{CHF}_{2} \mathrm{CF}_{2} \mathrm{SO}_{8} \mathrm{H}$ & 54 \\
\hline $\mathrm{CF}_{8} \mathrm{CF}=\mathrm{CF}_{2}$ & $\mathrm{NaHSO}_{3}$ & $\mathrm{CF}_{8} \mathrm{CHFCF}_{2} \mathrm{SO}_{8} \mathrm{H}$ & 44 \\
\hline $\mathrm{C}_{3} \mathrm{~F}_{7} \mathrm{CF}=\mathrm{CF}_{2}$ & " & $\mathrm{C}_{8} \mathrm{H}_{7} \mathrm{CHFCF}_{2} \mathrm{SO}_{8} \mathrm{H}$ & 79 \\
\hline $\mathrm{C}_{3} \mathrm{~F}_{11} \mathrm{CF}=\mathrm{CF}_{2}$ & " & $\mathrm{C}_{5} \mathrm{~F}_{11} \mathrm{CHFCF}_{2} \mathrm{SO}_{3} \mathrm{H}$ & 7 \\
\hline $\mathrm{CFCl}_{2} \mathrm{CF}_{2} \mathrm{CF}=\mathrm{CF}_{2}$ & " & $\mathrm{CFCl}_{2} \mathrm{CF}_{2} \mathrm{CFHCF}_{2} \mathrm{SO}_{3} \mathrm{H}$ & 69 \\
\hline $\begin{array}{l}\mathrm{Cl}\left(\mathrm{CFClCF}_{2}\right)_{2} \mathrm{CF}= \\
\mathrm{CF}_{2}\end{array}$ & " & $\begin{array}{l}\mathrm{Cl}\left(\mathrm{CFClCF}_{2}\right)_{2} \mathrm{CHFCF}_{2-} \\
\mathrm{SO}_{8} \mathrm{H}\end{array}$ & 57 \\
\hline
\end{tabular}

表 5 含フッ菜オンフィンと亜硫酸揾との反応 ${ }^{7,56,57)}$

5. C-F 結合の生成 フッ素イオンは弱い求核試
薬であるが使用する溶媒によっては含フッ素オレフィン を攻撃することができる。フッ化カリウムまたはナトリ ウムなどは protic な溶媒に溶解するが, 中間に生成す るフルオルカルバニオンがただちに溶媒よりプロトンを らばってしまう。

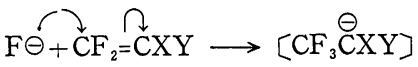

$$
\begin{aligned}
& \stackrel{\mathrm{H} \oplus}{\longrightarrow} \mathrm{CF}_{3} \mathrm{CHXY} \text {. }
\end{aligned}
$$

Miller ら ${ }^{58}$ はホルムアミドを溶媒としてフッ化カリウ ムを，またはクロルホルム, メチレンクロリド,アセトン などの溶媒中でテトラエチルアンモニウムフロリドを含 フッ素オレフィンに反応させて求核付加反応を行なった

一般に $=\mathrm{CF}_{2}$ 基への付加は $-\mathrm{CF}=\mathrm{CF}$-基への付加よりも 速い。フッ化カリウムーホルムアミド系で行なった例を表 6 に示した。本反応では中間に生成するフルオルカルバ ニオンが溶媒からプロトンをうばうために溶媒のアニオ ンが生成し，これとフッ素イオンとの競争反応がおこり 目的物の収率が低下する。

\begin{tabular}{|c|c|c|c|c|}
\hline $\begin{array}{l}\text { 舎フッ糸オレフ } \\
\text { イン }\end{array}$ & $\begin{array}{c}\text { 反応温度 } \\
\left({ }^{\circ} \mathrm{C}\right)\end{array}$ & $\begin{array}{c}\text { 反応時間 } \\
(\mathrm{hr})\end{array}$ & 生 成 物 & $\begin{array}{l}\text { 收率 } \\
(\%)\end{array}$ \\
\hline $\mathrm{CF}_{2}=\mathrm{CFCl}$ & 55 & 30 & $\mathrm{CF}_{8} \mathrm{CHFCl}$ & 72 \\
\hline $\mathrm{CF}_{2}=\mathrm{CFCF}_{8}$ & 25 & 5 & $\mathrm{CF}_{8} \mathrm{CHFCF}_{8}$ & 60 \\
\hline $\mathrm{CF}_{2}=\mathrm{CClCF}_{8}$ & 25 & 6 & $\mathrm{CF}_{8} \mathrm{CHClCF}_{8}$ & 61 \\
\hline $\mathrm{CF}_{8} \mathrm{CF}=\mathrm{CFCF}_{8}$ & 81 & 24 & $\mathrm{CF}_{8} \mathrm{CHFCF}_{2} \mathrm{CF}_{8}$ & 35 \\
\hline
\end{tabular}

表 6 含フッ秦オレフィンとホルムフミド中のフ化カ リウムとの反応

アリル位の炭素に $\mathrm{Cl}, \mathrm{Br}, \mathrm{I}$ などの置換した含フッ素オ レフィンでは付加反応より優先して $\mathrm{S}_{N} 2^{\prime}$ の反応がおこ $ろ^{58,59)}$

$$
\begin{aligned}
\mathrm{F} \ominus^{r}+\mathrm{CF}_{2}=\mathrm{CF}^{2}-\mathrm{CFCl} \\
\mathrm{Cl} \\
\mathrm{CF}_{3} \mathrm{CF}=\mathrm{CFCl}+\mathrm{Cl} \Theta
\end{aligned}
$$

アリル位の炭素に $\mathrm{F}$ が存在する場合も同様に反応し，こ の場合は異性化 ${ }^{60)}$ がおこる。たとえば $\mathrm{CF}_{2}=\mathrm{CFCF}=\mathrm{CF}_{2}$, $\mathrm{CF}_{2}=\mathrm{CFCF}_{2} \mathrm{CF}=\mathrm{CF}_{2}$ をフッ化セシウムと約 $100^{\circ} \mathrm{C}$ に加 熱すると，それぞれ $\mathrm{CF}_{3} \mathrm{C} \equiv \mathrm{CCF}_{3}, \mathrm{CF}_{3} \mathrm{C} \equiv \mathrm{CCF}_{2} \mathrm{CF}_{3}$ に 異性化し, $\mathrm{CF}_{2}=\mathrm{CFCF}_{2} \mathrm{CF}_{2} \mathrm{CF}=\mathrm{CF}_{2}$ 加ら $\mathrm{CF}_{3} \mathrm{C} \mathrm{CCF}_{2}$ $\mathrm{CF}_{2} \mathrm{CF}_{3}$ と $\mathrm{CF}_{3} \mathrm{CF}_{2} \mathrm{C} \equiv \mathrm{CCF}_{2} \mathrm{CF}_{3}$ とが得られる。反応機 構は〔37〕式のようなフッ素イオンによる $\mathrm{S}_{N} 2^{\prime}$ 反応と 考えられている。

$$
\begin{aligned}
& \mathrm{F} \Theta+\mathrm{CF}_{2}=\underset{\mathrm{F}}{\stackrel{\mathrm{F}}{\mathrm{C}}=\mathrm{CF}_{2}} \longrightarrow
\end{aligned}
$$

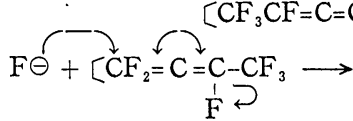

$$
\begin{aligned}
& {\left[\mathrm{CF}_{3} \mathrm{CF}=\mathrm{C}=\mathrm{CF}_{2}\right]+\mathrm{F} \Theta} \\
& \mathrm{CF}_{3} \mathrm{C} \equiv \mathrm{CCF}_{3}+\mathrm{F} \Theta
\end{aligned}
$$




\section{II. 環 化 反 応}

$\mathrm{CF}_{2}=\mathrm{CXY}$ の含フッ素オレフィンを $150 \sim 200^{\circ} \mathrm{C}$ に加 熱すると $\begin{aligned} & \mathrm{F}_{2} \\ & \mathrm{~F}_{2}\end{aligned}-\mathrm{XY}$ XY $\mathrm{XY}$ の環状二量体が収率よく生成するこ とは1946年 du Pont 社の Harmon ${ }^{61)}$ によってはじめ て報告された。この場合オレフィンのみでは重合反応が 優先するので重合禁止剤として Terpene B，ハイドロキ ノン,トリブチルアミンなどのアミン類, チオール類など を添加するか, 酸素を除去して反応を行なう。通常四員 環は五員環, 六員環と比較して結合角のひずみのために 不安定であるが，フッ素を多数含んだ四員環は特に安定 で，塩素化，ニトロ化などによっても簡単に開環しな い。

$\mathrm{CF}_{2}=\mathrm{CXY}$ と他種のオレフィン, ジエン, アセチレン などとを反応 ${ }^{62}$ させると環化して対応するシクロブタ

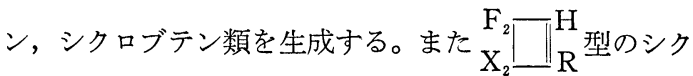
ロブテンを減圧下， $500 \sim 700^{\circ} \mathrm{C}$ に加熱すると $\mathrm{CF}_{2}=\mathrm{CH}$ $\mathrm{CR}=\mathrm{CX}_{2}$ の含フッ素ブタジエンが 表 7 に示したように 良好な收率で得られること䭪が明らかになってからは， 環化反応は含フッ素弹性体モノマーの合成法の一つとし ても注目されている。

表 7 含フッ素シクロブテンの熱分解による含フッ素 ジェンの合成

\begin{tabular}{|c|c|c|c|c|}
\hline シクロブテン & 生成ジェン & 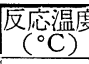 & \begin{tabular}{|l|} 
圧力 \\
$(\mathrm{mm})$
\end{tabular} & 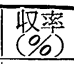 \\
\hline & $\mathrm{CF}_{2}=\mathrm{CHCH}=\mathrm{CF}_{2}$ & 700 & 10 & $\sim 100$ \\
\hline & $\mathrm{CF}_{2}=\mathrm{CHCCl}=\mathrm{CF}_{2}$ & 700 & 10 & 38 \\
\hline $\mathrm{F}_{2}{ }_{\mathrm{CH}_{2} \mathrm{CH}}^{\mathrm{H}}$ & $\begin{array}{l}\mathrm{CF}_{2}=\mathrm{CHC}\left(\mathrm{CH}_{2} \mathrm{OH}\right) \\
=\mathrm{CF}_{2}\end{array}$ & 650 & 1 & 50 \\
\hline $\mathrm{F}_{2} \square \mathrm{CH}_{2} \mathrm{Cl}$ & $\begin{array}{l}\mathrm{CF}_{2} \mathrm{CHC}\left(\mathrm{CH}_{2} \mathrm{Cl}\right)= \\
=\mathrm{CF}_{2}\end{array}$ & 550 & 10 & 100 \\
\hline $\mathrm{F}_{2}-\mathrm{C}_{\mathrm{C}_{6} \mathrm{H}_{3}}^{\mathrm{H}}$ & $\underset{\mathrm{CF}_{2}}{\mathrm{CF}_{2}=\mathrm{CHC}\left(\mathrm{C}_{6} \mathrm{H}_{5}\right)=}$ & 700 & 10 & 60 \\
\hline $\mathrm{F}_{2}{ }_{\mathrm{CO}_{2} \mathrm{CH}_{8}}^{\mathrm{H}}$ & $\begin{array}{l}\mathrm{CF}_{2}=\mathrm{CHC}\left(\mathrm{CO}_{2} \mathrm{C}-\right. \\
\left.\mathrm{H}_{8}\right)=\mathrm{CF}_{2}\end{array}$ & 525 & 10 & 55 \\
\hline $\mathrm{Cl}_{2}-\mathrm{CO}_{2} \mathrm{CH}_{3}$ & $\begin{array}{l}\mathrm{CF}_{2}=\mathrm{CHC}\left(\mathrm{CO}_{2} \mathrm{C}-\right. \\
\left.\mathrm{H}_{8}\right)=\mathrm{CCl}_{2}\end{array}$ & 550 & 10 & 90 \\
\hline $\mathrm{FCl}-\mathrm{CO}_{2} \mathrm{CH}_{3}$ & $\begin{array}{l}\mathrm{CF}_{2}=\mathrm{CHC}\left(\mathrm{CO}_{2} \mathrm{C}-\right. \\
\left.\mathrm{H}_{8}\right)=\mathrm{CFCl}\end{array}$ & 550 & 2 & 80 \\
\hline
\end{tabular}

1. 同種の含フッ素オレフイン環化 $\mathrm{CF}_{2}=\mathrm{CF}_{2}$ に重 合禁止剤を加えて 約 $200^{\circ} \mathrm{C}$ に加熱するか, または活性 炭を充テンした反応管中を $420 \sim 450^{\circ} \mathrm{C}$ で通過させると 容易にペルフルオルシクロブタンが生成する。しかし $1340^{\circ} \mathrm{C}$ に加熱した白金フイラメント中を通過させる場 合はへキサフルオルシクロプロパンが生成する ${ }^{61)}$ 。

$\mathrm{CF}_{2}=\mathrm{CXY}$ において $\mathrm{CF}_{2}=\mathrm{CF}_{2}, \mathrm{CF}_{2}=\mathrm{CFCl}, \mathrm{CF}_{2}=\mathrm{CCl}_{2}$ 等 ${ }^{64,65)}$ は 80 90\% の収率で環化するが, $\mathrm{CF}_{2}=\mathrm{CFBr}, \mathrm{CF}_{2}=$ $\mathrm{CBr}_{2}{ }^{65)}$ では $25 \sim 30 \%$ の収率にすぎずテロメル化が一 部おこる。

また $\mathrm{CF}_{2}=\mathrm{CFI}^{65)}$ ではペルフルオルシクロブテンのみ が生成する。さらに水素を含むオレフィン, $\mathrm{CF}_{2}=\mathrm{CHF}$, $\mathrm{CF}_{2}=\mathrm{CHBr}, \mathrm{CF}_{2}=\mathrm{CHCl}$ ではほとんど環化しない。 $\mathrm{CFCl}=$ $\mathrm{CFCl}$ では環状二量体よりはむしろ直鎖状の生成物 ${ }^{66)}$ を 与え，環化のためには=CF $\mathrm{CF}_{2}$ の存在が必要である。

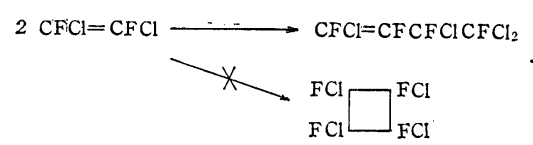

非対称のフルオルエチレンの環化の場合は head-he$a d$, tail-tail 型の付加物のみが得られる ${ }^{64)}$ 。しかし

$$
2 \mathrm{CF}_{2}=\mathrm{CCl}_{2} \longrightarrow \underset{\mathrm{F}_{2}}{\mathrm{~F}_{2}}-\mathrm{Cl}_{2}
$$

$\mathrm{CF}_{3}-\mathrm{CF}=\mathrm{CF}_{2}$ を苛酷な条件下で反応 ${ }^{67)}$ させる [40]式 のよらにペルフルオル(1,2-ジメチルシクロブタン)とペ ルフルオル (1,3-ジメチルシクロブタン) の両者が得ら れ,温度が低いと主として head-head 型の 1,2 構造が, 反応温度が上昇するにつれ head-tail 型の 1,3 構造が 増加してくる。

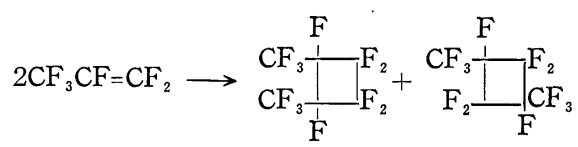

$\mathrm{CF}_{2}=\mathrm{CFCl}$ の環化により得られた 1,2-ジクロルヘキ サフルオルシクロブタンは反応が $130 \sim 225^{\circ} \mathrm{C}$ の温度範 囲ではシス (18) とトランス (19) がほぼ 50 対 50 であっ たが ${ }^{65)}$ ，ヘキサフルオルシクロブテンを光化学的に，あ るいは触媒を用いて塩素化すると生成した 1,2-ジク口 ルヘキサフルオルシクロブタンは主としてトランスのみ であった ${ }^{68)}$ 。

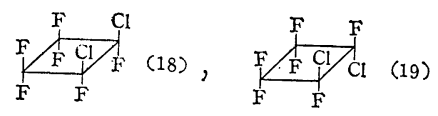

これら含フッ素オレフィンの 2 分子環化反応について はその機構として 2 種類提案されているがいまだ確定さ れていない*。

* 最近 Bartlett 599) は $\mathrm{CF}_{2}=\mathrm{CCl}_{2}$ そ 1,3-ブタジエン 2,4-へキサジ エンなどとの環化反応を行ない，生成した立体異性体の組成をしらへ 環化はジラジカル機構で進むことを報告している。 
その一つは鎖状ジラジカル構造 (A) であり, 他は four center 型 (B) である。
(A) $\mathrm{CF}_{2}=\mathrm{CFCl}$

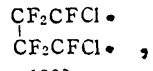
(20)
$\begin{array}{ll}\mathrm{CF}_{2} \mathrm{CFCl} & \stackrel{\mathrm{CFClCF}_{2}}{\mathrm{C}} \cdot \\ \mathrm{C} \mathrm{FClCF} & -\end{array}$ (21)
(22)
(B) $\mathrm{CF}_{2}=\mathrm{CFCl}$ $\frac{\mathrm{CF}_{2}-\mathrm{CFCl}}{\mathrm{C} \mathrm{F}_{2}-\mathrm{CFCl}}$ (23)
$\mathrm{CF}_{2}-\mathrm{CFCl}$
$\mathrm{CFCI}=\mathrm{CF}$ (24)

$\mathrm{Hine}^{69)}$ は $\mathrm{CF}_{2}=\mathrm{CF}_{2}, \mathrm{CF}_{2}=\mathrm{CFCl}$ の気相環化反応 ${ }^{70)}$ が 二次反応であること, 誘導期のないこと, 開始剤の不要 なことから four center 型71) の反応と推論した。しかし ながら前述のように非対称の含フッ素エチレンでは $h e$ ad-head 型の生成物のみが得られる。もし (B) のよう な遷移状態を経るとすれば，当然 (24)により 1,3-ジク ロルヘキサフルオルシクロブタンが同時に生成するはず であり，したがって生成物の構造を説明，推定するには (A) の方が都合が良い。ジラジカル説 (A) では遷移状 態において最低のエネルギー状態のジラジカルのみが選

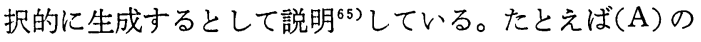
構造の中では（20）のジラジカルがもっとも安定である ため 1,2-ジクロル構造のものができると考えている。 もちろん反応温度を上昇するとエネルギーレベルの高い ジラジカルも生成し，1,3-構造のものも副生するはずで あるが，同時に生成したシクロブタン環の閶裂がおこ る。 $\mathrm{CF}_{3} \mathrm{CF}=\mathrm{CF}_{2}$ の環化の場合の可能なジラジカルは $\mathrm{CF}_{2} \mathrm{CFCF}_{3} \quad \mathrm{CF}_{2} \mathrm{CFCF}_{3} \quad \mathrm{CF}_{2}-\mathrm{CFCF}_{3}$ $\mathrm{CF}_{2} \dot{\mathrm{CFCF}}_{3}, \mathrm{CF}_{3} \dot{\mathrm{CF}} \stackrel{\mid}{\mathrm{CF}_{2}}, \quad \dot{\mathrm{CF}_{2}} \mathrm{CFCF}_{3}$ の 3 種が考えられるが， $-\dot{C}^{\circ} \mathrm{CFF}_{3}$ と - $\dot{C} F_{2}$ の安定性はあ まり差がないと推定される。それ故実際には 1,2 構造の ものと共に 1,3 構造のものが生成し, 後者は温度と共に 増加するが, $450^{\circ} \mathrm{C}$ ではシクロブタンの量が減少し, $\left(\mathrm{CF}_{3}\right)_{2} \mathrm{CF}=\mathrm{CF}_{2}$ が生成してくる。ジラジカル・CFXCF ${ }_{2}$ $\mathrm{CF}_{2} \mathrm{CFX}$ ・においてハロゲンXが遊離ラジカルを安定化 させる相対的な能力は $\mathrm{I}>\mathrm{Br}>\mathrm{Cl}>\mathrm{F}$ とされている。同 種オレフィン間の環化例を含フッ素アレンの場合も含め て表 8 にまとめた。

表 8 含フッ菜オレフィン環化反応

\begin{tabular}{|c|c|c|c|}
\hline 含フッ菜オレフィ & 生 成 & 物 & 収率 (\%) \\
\hline $\mathrm{CF}_{2}=\mathrm{CF}_{2}{ }^{65)}$ & $\begin{array}{l}\mathrm{F}_{2}-\mathrm{F}_{2} \\
\mathrm{~F}_{2}-\mathrm{F}_{2}\end{array}$ & & $80 \sim 90$ \\
\hline $\mathrm{CF}_{2}=\mathrm{CFCl}^{64)}$ & $\begin{array}{ll}\mathrm{F}_{2} & \mathrm{FCl} \\
\mathrm{F}_{2}-\mathrm{FCl}\end{array}$ & & 80 \\
\hline
\end{tabular}

\begin{tabular}{|c|c|c|}
\hline $\mathrm{CF}_{2}=\mathrm{CCl}_{2}{ }^{64)}$ & $\begin{array}{l}\mathrm{F}_{2} \\
\mathrm{~F}_{2}\end{array}-\left[\begin{array}{l}\mathrm{Cl}_{2} \\
\mathrm{Cl}_{2}\end{array}\right.$ & $80 \sim 85$ \\
\hline $\mathrm{CF}_{2}=\mathrm{CFBr}^{63)}$ & $\left.\begin{array}{l}\mathrm{F}_{2} \\
\mathrm{~F}_{2}\end{array}\right]\left[\begin{array}{l}\mathrm{FBr} \\
\mathrm{FBr}\end{array}\right.$ & 25 \\
\hline $\mathrm{CF}_{2}=\mathrm{CBr}_{2}{ }^{65)}$ & $\begin{array}{l}\mathrm{F}_{2} \\
\mathrm{~F}_{2}\end{array} \longrightarrow\left[\begin{array}{l}\mathrm{Br}_{2} \\
\mathrm{Br}_{2}\end{array}\right.$ & 28 \\
\hline $\mathrm{CF}_{2}=\mathrm{CFCN}^{20)}$ & $\begin{array}{ll}\mathrm{F}_{2} & \mathrm{~F} \cdot \mathrm{CN} \\
\mathrm{F}_{2} & \mathrm{~F} \cdot \mathrm{CN}\end{array}$ & 30 \\
\hline $\mathrm{CF}_{2}=\mathrm{CFCF}_{8}{ }^{67)}$ & 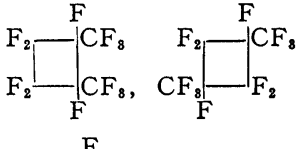 & $\sim 88$ \\
\hline $\left.\mathrm{CF}_{2}=\mathrm{CFSi}\left(\mathrm{CH}_{3}\right)_{8}{ }^{72}\right)$ & $\begin{array}{l}\mathrm{F}_{2}-\mathrm{Si}\left(\mathrm{CH}_{8}\right)_{8} \\
\mathrm{~F}_{2}-\mathrm{Si}\left(\mathrm{CH}_{8}\right)_{8}\end{array}$ & - \\
\hline $\mathrm{CF}_{2}=\mathrm{C}=\mathrm{CF}_{2}{ }^{78)}$ & $\begin{array}{l}\mathrm{F}_{2}=\mathrm{CF}_{2} \\
\mathrm{~F}_{2}=\mathrm{CF}_{2}\end{array}$ & 83 \\
\hline
\end{tabular}

2. 異種の含フッ素オレフイン間の環化 一般に同 種の含フッ素オレフィン間の場合より容易に環化反応が おこる。異種のオレフィン間。環化の例 ${ }^{7481)}$ は多数知 られており，その代表例を表 9 に示した。

表 9 異種のオンフィン間の環化

\begin{tabular}{|c|c|c|c|}
\hline $\begin{array}{l}\text { 念ファッ奖オ } \\
\text { レフィ }\end{array}$ & オレフィン & 生 成 物 & $\begin{array}{l}\text { 叕率 } \\
(\%)\end{array}$ \\
\hline $\mathrm{CF}_{2}=\mathrm{CF}_{2}$ & $\mathrm{CH}_{2}=\mathrm{CHCN}$ & $\int_{\mathrm{H}}^{\mathrm{F}_{2}}-\mathrm{CN}$ & 84 \\
\hline $\mathrm{CF}_{2}=\mathrm{CF}_{2}$ & $\mathrm{CH}_{2}=\mathrm{CHCHO}$ & $\left.\mathrm{H}_{2}\right|_{\mathrm{H}} ^{\mathrm{F}_{2}}-\mathrm{CHO}$ & 12 \\
\hline $\mathrm{CF}_{2}=\mathrm{CF}_{2}$ & $\begin{array}{l}\mathrm{CH}_{2}=\mathrm{C}\left(\mathrm{CH}_{8}\right) \mathrm{CO} \\
\mathrm{OCH}_{3}\end{array}$ & $\left.\right|_{\mathrm{CH}_{8}} ^{\mathrm{F}_{2}} \mathrm{COOCH}_{8}$ & 84 \\
\hline $\mathrm{CF}_{2}=\mathrm{CF}_{2}$ & $\mathrm{CH}_{2}=\mathrm{CHCOCH}_{8}$ & $\left.\mathrm{H}_{2}\right|_{\mathrm{H}} ^{\mathrm{F}_{2}} \mathrm{COCH}_{8}$ & 18 \\
\hline $\mathrm{CF}_{2}=\mathrm{CF}_{2}$ & $\mathrm{CH}_{2}=\mathrm{CHOCH}_{8}$ & $\mathrm{H}_{2} \mathrm{~F}_{\mathrm{H}}^{\mathrm{F}_{2}} \mathrm{-OCH}_{8}$ & 13 \\
\hline $\mathrm{CF}_{2}=\mathrm{CF}_{2}$ & $\mathrm{CH}_{2}=\mathrm{CHSi}\left(\mathrm{CH}_{3}\right)_{8}$ & $\left.\mathrm{H}_{2}\right|_{\mathrm{H}} ^{\mathrm{F}_{2}}-\mathrm{Si}\left(\mathrm{CH}_{3}\right)_{3}$ & 82 \\
\hline $\mathrm{CF}_{2}=\mathrm{CF}_{2}$ & $\mathrm{CF}_{2}=\mathrm{CFOCH}_{8}$ & $\left.\mathrm{~F}_{2}\right|_{\mathrm{F}} ^{\mathrm{F}_{2}}-\mathrm{OCH}_{3}$ & 65 \\
\hline $\mathrm{CF}_{2}=\mathrm{CF}_{2}$ & $\mathrm{CF}_{2}=\mathrm{CFCl}$ & $\mathrm{F}-\left.\right|_{\mathrm{F}} ^{\mathrm{F}_{2}}-\mathrm{FCl}$ & $\sim 100$ \\
\hline $\mathrm{CF}_{2}=\mathrm{CFCl}$ & $\mathrm{CH}_{2}=\mathrm{CHC}_{6} \mathrm{H}_{5}$ & $\mathrm{H}_{2}-\left.\right|_{\mathrm{H}} ^{\mathrm{F}_{2}}-\mathrm{C}_{6} \mathrm{H}_{5}$ & 67 \\
\hline
\end{tabular}




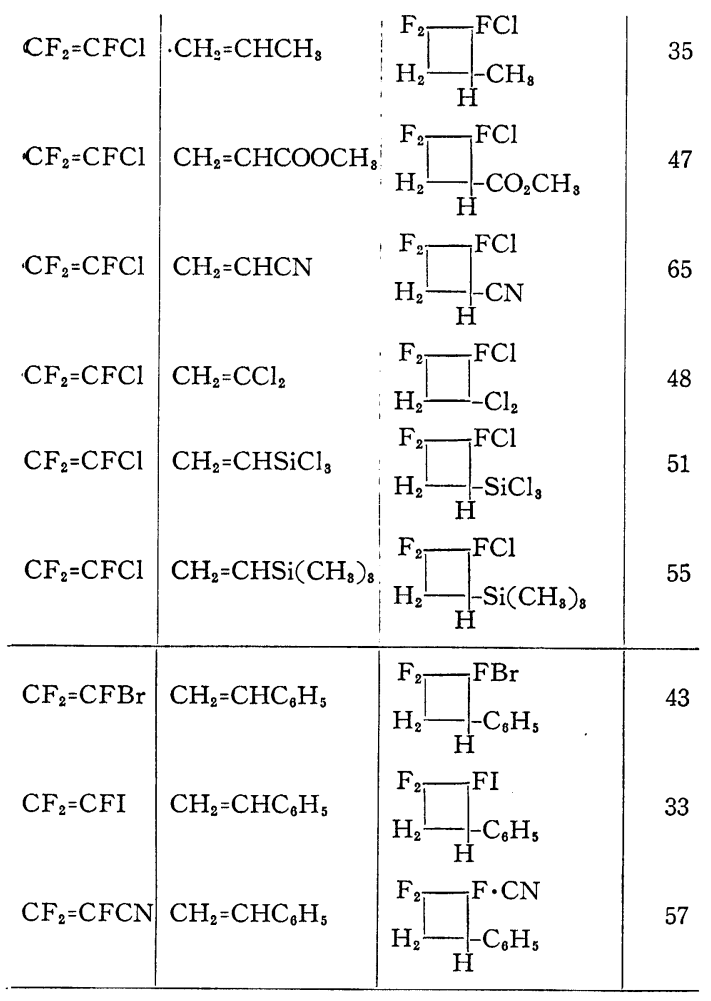

非対称オレフィンの場合は head-head の結合をす る。 $\mathrm{CF}_{2}=\mathrm{CF}_{2}, \mathrm{CF}_{2}=\mathrm{CFCl}$ と他のオレフィンとの反忘性を 比較すると一般に前者の方が低い温度で反応がすすみ, 収率も良い。スチレンと種々の含フッ素オレフィンとの 反応性 ${ }^{82}$ を転化率に基づいて比較すると次の通りであ る。 $\mathrm{CF}_{2}=\mathrm{CF}_{2}>\mathrm{CF}_{2}=\mathrm{CFCl}>\mathrm{CF}_{2}=\mathrm{CFCN}>$

$\mathrm{CF}_{2}=\mathrm{CFBr}>\mathrm{CF}_{2}=\mathrm{CFI} \gg \mathrm{CF}_{2}=\mathrm{CFCF}_{3} \fallingdotseq \mathrm{CF}_{2}=\mathrm{CHF}$

この傾向は 1. で記述した同種間の含フッ素オレフィ ンの環化の反応性とほぼ同じである。上記の構造による 反応性の差異についてはその理由がはっきりしておら ず，電子論的，あるいは立体的な因子のみで説明するこ とは困難である。たとえば $\mathrm{CF}_{3} \mathrm{CF}=\mathrm{CF}_{2}$ と $\mathrm{CF}_{2}=\mathrm{CFCN}$

表 $10 \quad \mathrm{CF}_{2}=\mathrm{CF}_{2}$ とオンフィンとの環化 ${ }^{62)}$

\begin{tabular}{l|c}
\hline \multicolumn{1}{c|}{ オフ } & 生成シクロブタン収率(\%) \\
\hline $\mathrm{CH}_{2}=\mathrm{CH}_{2}$ & 40 \\
$\mathrm{CH}_{3} \mathrm{CH}=\mathrm{CH}_{2}$ & 72 \\
$\left(\mathrm{CH}_{8}\right)_{2} \mathrm{C}=\mathrm{CH}_{2}$ & 30 \\
$\mathrm{C}_{6} \mathrm{H}_{5} \mathrm{CH}=\mathrm{CH}_{2}$ & 85 \\
$\mathrm{CH}_{3} \mathrm{CH}=\mathrm{CHCH}$ & 5 \\
$\mathrm{CH}_{2}=\mathrm{CHCl}$ & 23 \\
$\mathrm{CH}_{2}=\mathrm{CCl}$ & 46 \\
$\mathrm{CHCl}_{2}$ & 18 \\
$\mathrm{CH}_{2}=\mathrm{CHCl}_{2}$ & 42 \\
$\mathrm{CH}_{2}=\mathrm{C}\left(\mathrm{CH}_{3}\right) \mathrm{CH}_{2} \mathrm{Cl}$ & 45 \\
\hline
\end{tabular}

とを比較した場合, $\mathrm{CF}_{3}$ 基と $\mathrm{CN}$ 基との置換基の大き さおよび電子吸引性の相違では反応性の大きな違いを説 明できないし， $\mathrm{CF}_{2}=\mathrm{CFI}$ はスチレンと環化するが $\mathrm{CF}_{2}=$ CHF はほとんど環化しないというのも立体的な因子で は説明できない。

環化の難易は相手のオレフィンの構造にも影響され る。 $\mathrm{CF}_{2}=\mathrm{CF}_{2}$ との環化例を 表 10 に示す。

\section{3. 含フッ素オレフインとジエンおよびアレンとの環} 化 含フッ素オレフィンとジェンとの環化 ${ }^{62)}$ は前記の 四員環化と Diels-Alder 反応による六員環化の両者が可 能である。 $\mathrm{CF}_{2}=\mathrm{CF}_{2}$ を 1,3-ブタジエンと重合禁止剤の 添加下で $125^{\circ} \mathrm{C}$ に加熱すると $90 \%$ の収率で 1-ビニル -2, 2, 3, 3-テトラフルオルシクロブタン (25) が得られ, Diels-Alder 反応によって予期されるテトラフルオルシ クロヘキセンは生成しなかった。(25)をさらに $\mathrm{CF}_{2}=\mathrm{CF}_{2}$ と反応させるとオクタフルオルビシクロブチル (26) と なる。また(25) を減圧下で加熱すると含フッ素シクロ ヘキセンとなる。
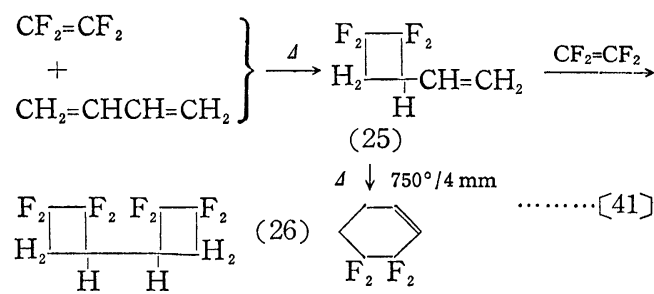

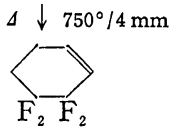

$\mathrm{CF}_{2}=\mathrm{CFX}$ と 1,3-ブタジェンとの環化反応において, $\mathrm{X}=\mathrm{F}, \mathrm{Cl}, \mathrm{Br}, \mathrm{I}$ の時 は生成物は四員環（27）のみであっ た。また $\mathrm{X}=\mathrm{CH}_{2} \mathrm{CH}_{2} \mathrm{Si}\left(\mathrm{CH}_{3}\right)_{3}{ }^{72)}$ の場合も四員環のみが 生成したが, $\mathrm{X}=\mathrm{CF}_{3}, \mathrm{CN}, \mathrm{CH}_{2} \mathrm{CH}_{2} \mathrm{Br}$ の場合には四員環 （27）と六員環 (28) の両者が共に生成した。

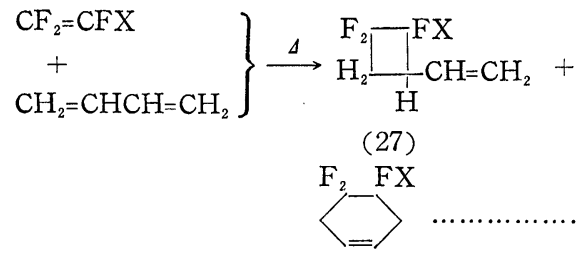

(28)

環化の容易さほほぼXの電気陰性度が小さくなるにつれ て減少し，次の傾向にある。

$$
\mathrm{X}=\mathrm{Cl}>\mathrm{CN}>\mathrm{Br}>\mathrm{I}>\mathrm{CF}_{3}>\mathrm{CH}_{2} \mathrm{CH}_{2} \mathrm{Br}>\mathrm{H}
$$

$\mathrm{CF}_{2}=\mathrm{CF}_{2}$ と $\mathrm{CH}_{2}=\mathrm{CHCY}=\mathrm{CH}_{2}$ との環化では $1: 1$ 付 加物として (29), (30) の両者が可能であるが, $\mathrm{Y}=\mathrm{CH}_{3}$, $\mathrm{Cl}, \mathrm{F}$ の場合は 表 11 のようにYの電子吸引性が増加す るにつれて（30）の割合が増加する。 
表 $11 \mathrm{CF}_{2}=\mathrm{CF}_{2}$ と $\mathrm{CH}_{2}=\mathrm{CH}-\mathrm{CY}=\mathrm{CH}_{2}$ との環化

\begin{tabular}{|c|c|c|c|}
\hline $\mathrm{Y}$ & 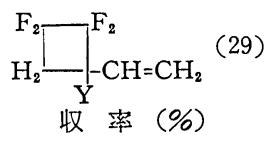 & $\begin{array}{l}\mathrm{F}_{2}-\mathrm{F}_{\mathrm{H}}^{\mathrm{F}}-\mathrm{CY}=\mathrm{CH}_{2} \\
\mathrm{H}_{2} \text { 率 }(\%)\end{array}$ & (30) \\
\hline $\mathrm{CH}_{8}$ & 83 & 0 & \\
\hline $\mathrm{Cl}$ & 51 & 10 & \\
\hline $\mathrm{F}$ & 35 & 35 & \\
\hline
\end{tabular}

$\mathrm{CF}_{2}=\mathrm{CF}_{2}$ と $\mathrm{CH}_{2}=\mathrm{CHCH}=\mathrm{CHCH}_{3}$ からは $68 \%$ の収率 で $\mathrm{H}_{1} \frac{\mathrm{F}_{2}-\left.\right|_{\mathrm{H}} ^{\mathrm{F}}}{\mathrm{H}} \mathrm{CH}=\mathrm{CHCH}_{3}$ のみが得られた。

$\mathrm{CF}_{2}=\mathrm{CF}_{2}$ とシクロ-1,3-ジェンとの反応 ${ }^{83)}$ は [43]式 のような生成物を与える。この反応を利用し ${ }^{84)} ， 3$ 工程 でトロポロンおよびその誘導体が良好な収率で得られて いる。

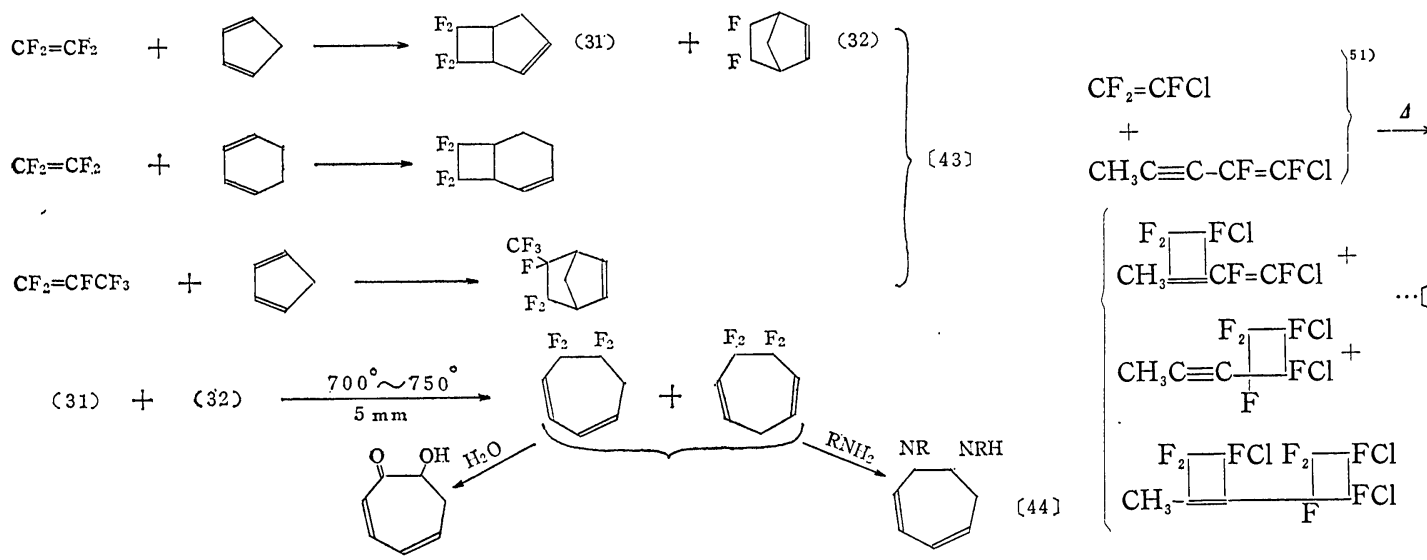

共役 enyne との反応 ${ }^{62)}$ は 3. の場合と同様四員環化と Diels-Alder 反応との可能性があるため生成物はさらに 複雑となる。一般に四員環化の方が Diels-Alder 反応 に優先しておこる。例を〔47],〔48】式に示した。

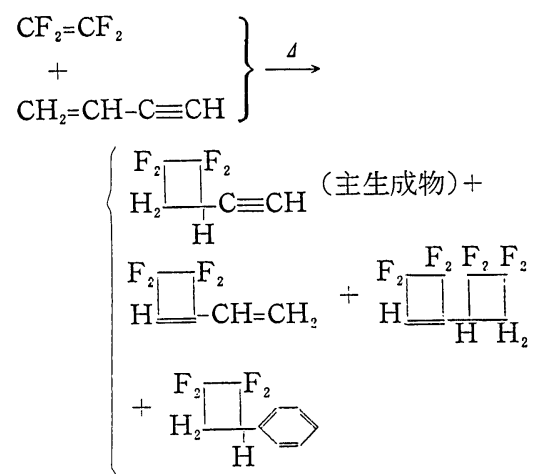

$\mathrm{CF}_{2}=\mathrm{CF}_{2}$ とアレンとの反応では $1: 1$ 付加物と $1: 2$ 付加物とが得られた。

$$
\begin{aligned}
\mathrm{CF}_{2}=\mathrm{CF}_{2}+\mathrm{CH}_{2}=\mathrm{C}=\mathrm{CH}_{2} \stackrel{\Delta}{\longrightarrow} \\
\stackrel{\mathrm{F}_{2}-\mathrm{CH}_{2}+\mathrm{F}_{2} \longrightarrow \mathrm{F}_{2}}{\longrightarrow} \mathrm{F}_{2}
\end{aligned}
$$

4. 含フッ素オレフインとアセチレンとの環化 ア セチレンと含フッ素オレフィンとを環化させるとシクロ ブデンが生成するが，これを加熱すると含フッ素 1,3ブタジエンが得られる。Anderson ${ }^{85)}$ はこれを利用し，

1 工程で 1,1,4,4-テトラフルオルブタジエンを合成し た。

$$
\begin{array}{r}
\left.\begin{array}{c}
\mathrm{CF}_{2}=\mathrm{CF}_{2} \\
+ \\
\mathrm{CH} \equiv \mathrm{CH}
\end{array}\right\} \stackrel{600^{\circ} \longrightarrow}{\longrightarrow}\left(\begin{array}{c}
\mathrm{F}_{2} \underset{\mathrm{F}_{2}}{\mathrm{~F}} \\
\mathrm{H}
\end{array}\right) \longrightarrow \\
\mathrm{CF}_{2}=\mathrm{CHCH}=\mathrm{CF}_{2}
\end{array}
$$

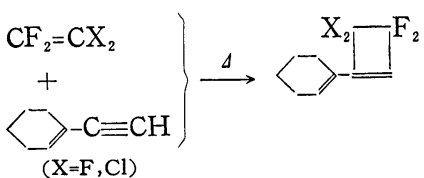

Roberts ら ${ }^{86)}$ はオレフィン，アセチレンと含フッ素オ レフィンとの環化によって得られたシクロブタン，シク ロブテン誘導体を利用して種々の新らしい四員環誘導体 を合成している。たとえば

$$
\begin{aligned}
& \left\langle-\mathrm{C} \equiv \mathrm{CH}+\mathrm{CF}_{2}=\mathrm{CX}_{2} \stackrel{\Delta}{\longrightarrow}\right. \\
& \underset{\mathrm{H}_{2} \mathrm{O}}{\stackrel{\mathrm{H}_{2} \mathrm{SO}_{4}}{\longrightarrow}}
\end{aligned}
$$

5. 含フッ素オレフインと $\mathrm{C}=\mathrm{O}, \mathrm{N}=\mathrm{O}, \mathrm{S}=\mathrm{O}$ を含む化 合物との環化

i. $\mathbf{C}=\mathbf{O}$ 
含フッ素オレフィンと脂肪族アルデヒドとを過酸化物

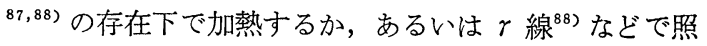
射すると, ラジカル付加反応によって対応する含フッ素 ケトンが得られるが，含フッ素アルデヒドの場合 ${ }^{89}$ には アルデヒド基の Hの引き抜きが困難なためむしろ環化し て oxetane が生成する。

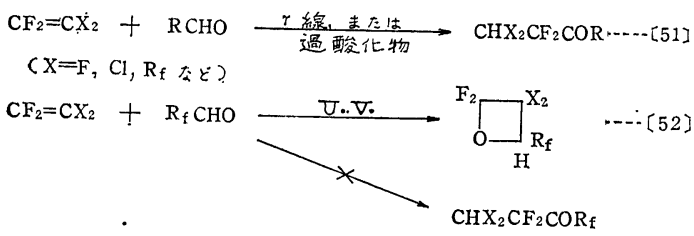

同様な環化は含フッ素ケトン，含フッ素酸フロリドの場 合 ${ }^{89}$ にも認められる。代表的な例を表 12 に示す。

表 12 紫外線照射による含フッ素オレフィンとカルボニ ル化合物との環化

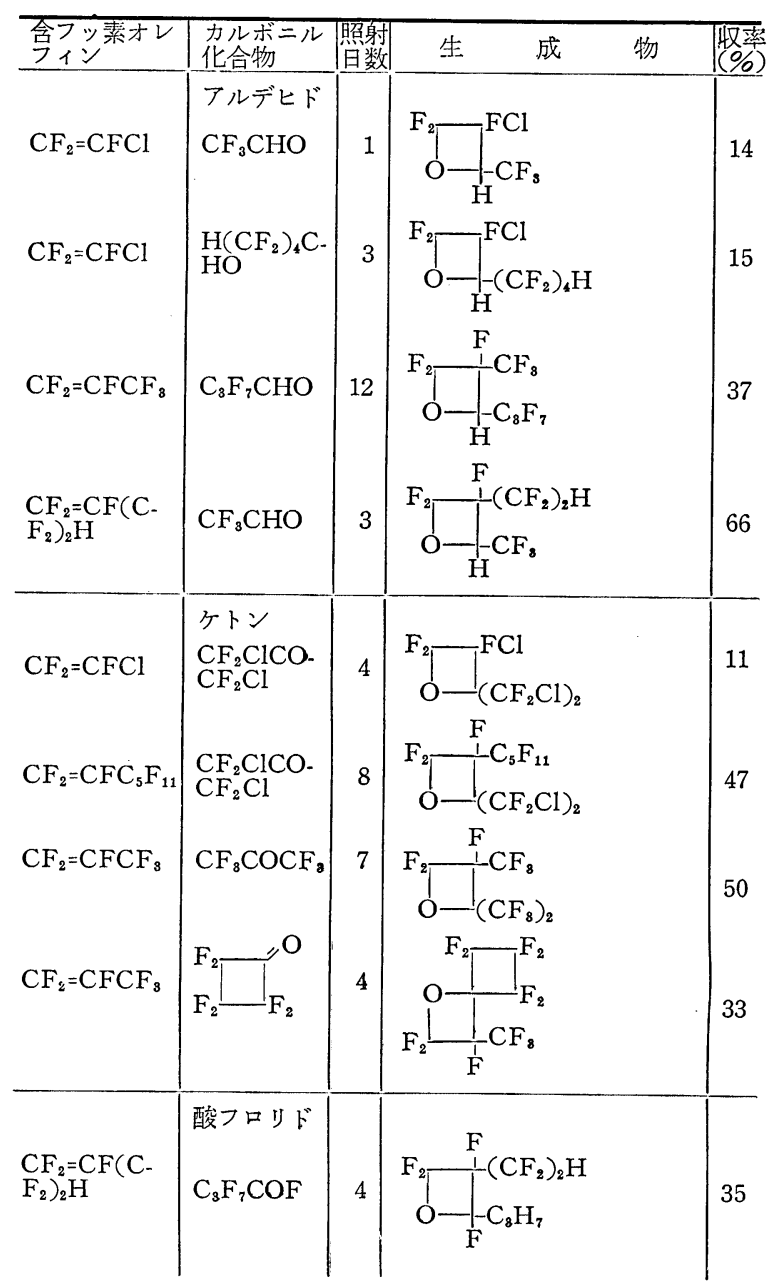

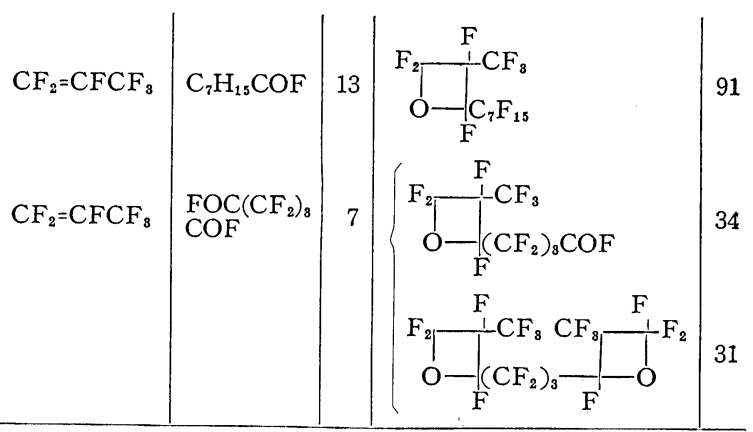

環化が four center 機構か，ジラジカル機構かは明ら かでないが 1.で述べたようにジラジカル機構によれば 生成物の構造の説明, 推定に便利である。たとえば, $\mathrm{CF}_{3} \mathrm{CF}=\mathrm{CF}_{2}$ と $\mathrm{CF}_{3} \mathrm{CHO}$ との環化では考えられる次の 4 つのジラジカルの中で (33) がもっとも安定と考えら れ，実際の生成物と一致する。

${\mathrm{O}-\mathrm{CHCF}_{3}}_{3} \mathrm{O}-\mathrm{CHCF}_{3} \quad \mathrm{O}-\mathrm{CHCF}_{3} \quad \mathrm{O}-\mathrm{CH}-\mathrm{CF}_{3}$

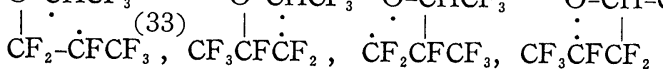

最近 Bissell ら ${ }^{90}$ は $\mathrm{CF}_{2}=\mathrm{CX}_{2}(\mathrm{X}=\mathrm{F}, \mathrm{Cl}, \mathrm{Br})$ と $\mathrm{CH}_{3}$. $\mathrm{CHO}$ との気相紫外線照射を行ない, ラジカル付加によ る含フッ素ケトンと共に, 少量の対応する Oxetane を 得ている。

また含フッ素オレフィンとペルフルオルシクロブタノ ン $(34)^{91)}$ との環化も行なわれている。
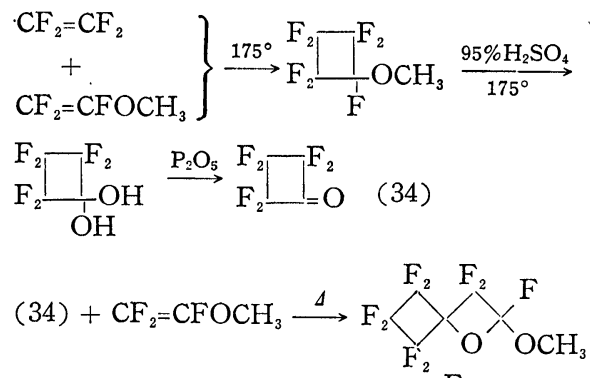

(34) $+\mathrm{CH}_{2}=\mathrm{CHCH}=\mathrm{CH}_{2} \stackrel{\Delta}{\longrightarrow}$

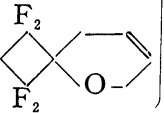

このペルフルオルシクロブタノンは通常の不飽和化合物 とは環化しないでシクロブタノールとなる。

(34) $+\mathrm{CH}_{3} \mathrm{CH}=\mathrm{CH}_{2} \longrightarrow$

$$
\mathrm{F}_{2} \frac{\mathrm{F}_{2}-\mathrm{F}_{\mathrm{O}}}{\mathrm{OH}} \mathrm{FH}_{2} \mathrm{CH}=\mathrm{CH}_{2}
$$

\section{ii $\mathbf{N}=\mathbf{O}$}

ペルフルオルアルキルニトロソ化合物と含フッ素オレ フィンとの反応によって環化と重合とがおこることは Haszeldine 一派によって見出され，特に重合によって 
得られたポリマーは低温でも弾性を有するエラストマー のため活発な研究が続けられている。たとえば $\mathrm{CF}_{3} \mathrm{~N}=\mathrm{O}$ と $\mathrm{CF}_{2}=\mathrm{CF}_{2}$ とを反応 ${ }^{92)}$ させると Oxazetidine (35) と ポリマー（36）とが得られ，低温では主としてポリマー が，高温では Oxazetidine が生成する。含フッ素オレ フィンとしては $\mathrm{CF}_{2}=\mathrm{CF}_{2}, \mathrm{CF}_{2}=\mathrm{CFCl}, \mathrm{CF}_{2}=\mathrm{CCl}_{2}, \mathrm{CF}_{2}=\mathrm{C}$ $\mathrm{FH}, \mathrm{CF}_{2}=\mathrm{CFCF}_{3}{ }^{93)}$ などが用いられている。

$$
\begin{aligned}
& \mathrm{CF}_{2}=\mathrm{CX}_{2}+\mathrm{CF}_{3} \mathrm{~N}=\mathrm{a} \\
& \left(\mathrm{X}=\mathrm{F}, \mathrm{Cl}, \mathrm{H}, \mathrm{CF}_{3}\right. \text { ) } \\
& \left\{\begin{array}{l}
\mathrm{F}_{2}-\mathrm{X}_{2} \\
\mathrm{O}-\mathrm{N}-\mathrm{CF}_{3} \\
\underset{\mathrm{CF}_{3}}{\left.\mathrm{E}-\mathrm{O}-\mathrm{CF}_{2} \mathrm{CX}_{2}\right]_{\mathrm{n}}}
\end{array}\right.
\end{aligned}
$$

含フッ素ニトロソ化合物としては種々のものが合成さ れているが，2,3 例を示すと，

$$
\begin{gathered}
\mathrm{CF}_{2}=\mathrm{CFI}+\mathrm{NO} \underset{\mathrm{Hg}}{\stackrel{\mathrm{h} \nu}{\longrightarrow}} \mathrm{CF}_{2}=\mathrm{CF} \cdot \mathrm{N}=\mathrm{O}+\mathrm{HgI}_{2} \\
\mathrm{CF}_{2}=\mathrm{CFX} \\
\mathrm{CF}_{2}=\mathrm{CF}-\mathrm{N}=\mathrm{O} \\
\quad(\mathrm{X}=\mathrm{F}, \mathrm{Cl})
\end{gathered}
$$

$2 \mathrm{CF}_{2}=\mathrm{CF}-\mathrm{N}=\mathrm{O}^{95)} \frac{80^{\circ}}{40 \sim 60 \mathrm{~atm}}$

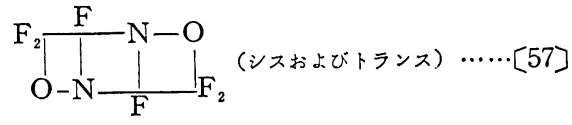

$\mathrm{CF}_{2}=\mathrm{CF}_{2}+\mathrm{NO} \stackrel{20^{\circ}}{\longrightarrow} \mathrm{NO}_{2} \mathrm{CF}_{2} \mathrm{CF}_{2} \mathrm{~N}=\mathrm{O}$

$$
\begin{aligned}
& \begin{array}{c}
\mathrm{CF}_{2}=\mathrm{CF}_{2} \\
\mathrm{NO}_{2} \mathrm{CF}_{2} \mathrm{CF}_{2} \mathrm{NO}
\end{array} \\
& \qquad \\
&
\end{aligned}
$$

$$
\begin{aligned}
& \mathrm{CF}_{2}=\mathrm{CF}_{2}{ }^{97)} \\
& + \\
& \mathrm{NOX}
\end{aligned} \longrightarrow\left[\mathrm{CF}_{2} \mathrm{XCF}_{2} \mathrm{~N}=\mathrm{O}\right]
$$

$(\mathrm{X}=\mathrm{F}, \mathrm{Cl})$

$$
\stackrel{\mathrm{CF}_{2}=\mathrm{CF}_{2}}{\longrightarrow}\left\{\begin{array}{c}
-\mathrm{N}-\mathrm{O}-\mathrm{CF}_{2} \mathrm{CF}- \\
\mathrm{l} \mathrm{CF}_{2} \mathrm{CF}_{2} \mathrm{X}_{2} \\
+ \\
\mathrm{F}_{2} \underset{\mathrm{n}}{\mathrm{F}} \mathrm{F}_{2} \\
\mathrm{O}-\mathrm{N}-\mathrm{CF}_{2} \mathrm{CF}_{2} \mathrm{X}
\end{array}\right.
$$

含フッ素オレフィンと $\mathrm{SO}_{3}$ との環化 ${ }^{98)}$.では次のよう な sultone 類が好收率で得られる。

$$
\begin{aligned}
& \left.\begin{array}{c}
\mathrm{CF}_{2}=\mathrm{CFX} \\
+ \\
\mathrm{SO}_{3}
\end{array}\right\} \rightarrow \underset{\mathrm{O}-\mathrm{SO}_{2}}{\mathrm{~F}} \\
& \mathrm{CF}_{2}=\mathrm{CFCl} \text { との反㐫では } \underset{\mathrm{O}-\mathrm{SO}_{2}}{\mathrm{~F}_{2}}{ }_{\mathrm{O}-\mathrm{SO}_{2}}^{\mathrm{FCl}} \text { と }
\end{aligned}
$$

がほぼ等量得られた。

$\mathrm{CF}_{2}=\mathrm{CHF}$ からは対応する sultone (60\%) と共に $\mathrm{FH}{\underset{\mathrm{S}}{\mathrm{O}_{2}^{\prime}}}_{\mathrm{O}_{2}^{\prime}}^{\mathrm{O}_{2}} \mathrm{~S}_{2}(34 \%)$ が生成した。

\section{III. むすび}

以上含フッ素オレフィンの数多くの反応の中, 求核付 加反応と環化反応のみに焦点をしぼって記述した。著者 らの研究室では含フッ素オレフィンへのラジカル付加反 応について研究を続けているが，この分野については割 愛した。興味ある報告はほとんど取り上げた積りだが， 見落しや，考え違いもあることと思うのでご教示下され ば幸いである。

(昭和 39 年 6 月 4 日受理)

$$
\text { 文献 }
$$

1）一般的な反応については次の成書が参考になる。 A.M. Lovelace, D.A. Rausch, W. Postelnek, "Aliphatic Fluorine Compounds" (1958); J. H. Simons 編, “Fluorine Chemistry" VoI (1950) Vol II (1954); M. Hudlicky "Chemistry of Organic Fluorine Compounds" (1962)

2) 箕浦, 斎藤, 有合化 1994 (1961)

3）高木, 浅原, 有合化 19172 (1961)

4) 右田, 徳丸, 有合化 19821 (1961); 右田, 伊藤, 徳丸 ibid. 22241 (1964)

5) W. E. Hanford, G. W. Rigby, USP 2, 409, 274 (1946); BP 583, 874 (1947)

6) W.T. Miller, Jr., E.W. Fager, P.H. Griswold, J. Am. Chem. Soc. 70431 (1948)

7) D.D. Coffman, M.S. Raasch, G.W. Rigby, P. L. Barrick, W.E. Hanford, J. Org. Chem. 14 747 (1949); J.D. Park, M.L. Sharrah, W.H. Breen, J.R. Lacher, J. Am. Chem. Soc. 73 1329 (1951)

8) J.D. Park, D.K. Vail, K.R.Lea, J.R. Lacher, J. Am. Chem. Soc. 701550 (1948); P. Tarrant, H.C. Brown, ibid. 731781 (1951)

9) J.D. Park, C.M. Snow, 'J.R. Lacher, J. Am. Chem. Soc. 73861 (1951); A. Demiel, J. Org. Chem. 25993 (1960)

10) J.D. Park, W.R. Lycan, J.R. Lacher, J. Am. 
Chem. Soc. 73711 (1951)

11) J.D. Park, H.L. Cummings, J.R. Lacher, J. Org. Chem. 231785 (1958)

12) M.L. Brey, P. Tarrant, J. Am. Chem. Soc. 79 6533 (1957); J.K. Lawson, Jr., USP 2, 631, 975 (1953) ; J.D. Park, J.G. Abramo, J.R. Lacher, J. Org. Chem. 231394 (1958)

13) P. Tarrant, H.C. Brown, J. Am. Chem. Soc. 735831 (1951)

14) J.D. Park, E. Halpern, J.R. Lacher, J. Am. Chem. Soc. 744104 (1952)

15) J.D. Park, W.M. Sweeney, S.L. Hopwood, Jr., J.R. Lacher, J. Am. Chem. Soc. 781685 (1956)

16) R.J. Koshar, T.C. Simmons, F.W. Hoffmann, J. Am. Chem. Soc. 791741 (1957)

17) I.L. Knunyants, L.S. German, B.L. Dyatkin, Izvest. Akad Nauk, S.S.S.R., Otdel. Khim. Nauk 1353 (1956); C.A. 518037 (1957)

18) I.L. Knunyants, B.L. Dyatkin, L.R. German, Doklady Akad. Nauk, S.S.S.R. 1241065 (1959); C.A. 5314920 (1959)

19) I.L. Knunyants, B.L. Byatkin, E.P. Mochalina, Izvest. Akad. Nauk, S.S.S.R. Otdel. Khim. Nauk 1483 (1962); C.A. 581324 (1963)

(20) J.D. LaZerte, D.A. Rausch, R.J. Koshar, J.D. Park, W.H. Pearlson, J.R. Lacher, J. Am. Chem. Soc. 785639 (1956)

21) R.A. Shepard, H. Lessoff, J.D. Domijan, D.B. Hilton, T.F. Finnegan, J. Org. Chem. 232011 (1958)

22) J.D. Park, M.L. Sharrah, J.R. Lacher, J. Am. Chem. Soc. 712337 (1949)

23) J.T. Barr, K.E. Rapp, R.L. Pruett, C.T. Bahner, J.D. Gibson, R.H. Lafferty, Jr., J. Am. Chem. Soc. 724480 (1950); ibid. 74749 (1952)

24) J.D. Park, C.M. Snow, J.R. Lacher, J. Am. Chem. Soc. 732342 (1951)

25) D.W. Chaney, USP 2,443,024 (1948)

26) R. Meier, F. Böhler, Ber. 902342 (1957)

27) E.F. Silberssmith, D. Smith, J. Org. Chem. 23427 (1958)

28) S. Dixon, USP 2, 917, 548 (1959); K Okhara, H. Baba, R. Kojima, Bull. Chem. Soc. Japan 35532 (1962)

29) A.P. Stefani, J.R. Lacher, J.D. Park, J. Org. Chem. 25676 (1960)

30) D.C. England, L.R. Melby, M.A. Dietrich, R. V. Lindsey, Jr., J. Am. Chem. Soc. 825116 (1960)

31) E.I. du Pont de Nemours \& Co., BP 904,877 (1962)

32) J.D. LaZerte, USP 2, 704, 769 (1955)

33) W.L. Reilly, H.C. Brown, J. Am. Chem. Soc.
786032 (1956); J. Org. Chem. 22698 (1957)

34) W.T. Miller, USP 2, 691, 036 (1954)

35) G.W. Rigby, H.E. Schroeder, USP 2, 409, 315 (1946)

36) R.L. Pruett, J.T. Barr, K.E. Rapp, C.T. Bahner, J.D. Gibson, R.H. Lafferty, Jr., J. Am. Chem. Soc. 723646 (1950)

37) I.L. Knunyants, International Symposium of Fluorine Chemistry, Birmingham 1959

38) I.L. Knunyants, B.L. Dyatkin, L.S. German, Doklady Akad Nauk S.S.S.R. 1241065 (1959), ;C.A. 5314920 (1959)

39) I.L. Knunyants, B.L. Dyatkin, L.S. German, Khim. Nauk i Prom. 3828 (1958); C.A. 53 10207 (1959)

40) C.S. Cleaver, D.C. England, USP 2,861,990 (1958)

41) R.A. Carboni, R.V. Lindsey, Jr., J. Am. Chem. Soc. 805793 (1958); R.A. Carboni, USP $2,817,622$ (1957)

42) I.L. Knunyants, E.G. Bykhovskaya, V.N. Frosin, Deklady Akad. Nauk S.S.S.R. 127337 (1959); C.A. 54259 (1960)

43) I.L. Knunyants, E.G. Bykhovskaya, Zh. Vses. Khim. Obshchestva im D.I. Mendeleeva 7585. (1962); C.A. 585509 (1963)

44) I.L. Knunyants. E.G. Bykhovskaya, Doklady. Akad. Nauk S.S.S.R. 1311338 (1960); C.A. 5420840 (1960)

45) D.C. England, R.V. Lindsey, Jr.,, L.R. Melby, J. Am. Chem. Soc. 806442 (1958); D.C. England, USP 2, 802, 028 (1957)

46) P. Tarrant, D.A. Warner, J. Am. Chem. Soc. 761624 (1954)

47) S. Dixon, J. Org. Chem. 21400 (1957)

48) R. Meier, F. Böhler, Ber. 902344 (1957)

49) R. Meier, F. Böhler, Ber. 902350 (1957)

50) D. Seyferth, T. Wada, Inorg. Chem. 178 (1962)

51) P. Tarrant, J. Savory, 私信による。

52) W.E. Hanford, USP 2, 443, 003 (1948)

53) K.E. Rapp, R.L. Pruett, J.T. Barr, C.T. Bahner, J.D. Gibson, R.H. Lafferty, Jr., J. Am. Chem. Soc. 723642 (1950)

54) I.L. Knunyants, A.V. Fokin, Izvest. Akad.. Nauk S.S.S.R., Otdel. Khim. Nauk 261 (1952); C.A. 473221 (1953)

55) P.L. Barrick, USP 2, 403, 207 (1946)

56) R.J.Koshar, P.W. Trott, J.D. La Zerte, J. Am. Chem. Soc. 754595 (1953)

57) R.N. Haszeldine, J. Chem. Soc. 4291 (1955)

58) W.T. Miller, Jr., J.H. Eried, H. Goldwhite, J. Am. Chem. Soc. 823091 (1960)

59) J.H. Fried, W.T. Miller, Jr., J. Am. Chem. Soc. 812078 (1959) 
60) W.T. Miller, Jr., W. Frass, P.R. Resnick, J. Am. Chem. Soc. 831767 (1961)

61) J. Harmon, USP 2, 404, 374 (1946)

62) D.D. Coffman, P.L. Barrick, R.D. Cramer, M.S. Raasch, J. Am. Chem. Soc. 71490 (1949)

63) J.L. Anderson, R.E. Putnam, W.H. Sharkey, J. Am. Chem. Soc. 83382 (1961)

64) A.L. Henne, R.P. Ruh, J. Am. Chem. Soc. 69279 (1947)

65) J.D. Park, H.V. Holler, J.R. Lacher, J. Org. Chem. 25990 (1960); J.D. Park, R.J. Seffl, J.R. Lacher, J. Am. Chem. Soc. 7859 (1956)

66) R.N. Haszeldine, J.E. Osborne, J. Chem. Soc. 3880 (1955)

67) M. Hauptschein, A.H. Fainberg, M. Braid, J. Am. Chem. Soc. 80842 (1958)

68) J.R. Lacher, A. Buchler, J.D. Park, J. Chem. Phys. 201014 (1952)

69) J. Hine, "Physical Organic Chemistry" p.514, 2 nd Ed. (1962)

70) J.R. Lacher, G,W. Tompkin, J.D. Park, J. Am. Chem. Soc. 741693 (1952)

71) A.L. Barney, T.L. Cairns, J. Am. Chem. Soc. 723193 (1950)

72) P. Tarrant, W. Oliver，私信による。

73) T.L. Jacoks, R.S. Bauer, J. Am. Chem. Soc. 81606 (1959)

74) P.L. Barrick, USP 2, 427, 116 (1947); ibid 2, 462, 345 (1949); P.L. Barrick, R.D. Cramer, ibid. 2, 441, 128 (1948); A.N. Sachanen, ibid. 2, 582, 283 (1951)

75) M,S. Raasch, R.E. Miegel, J.E. Castle, J. Am. Chem. Soc. 812678 (1959)

76) R.E. Benson, R.V. Lindsey, Jr., J. Am. Chem. Soc. 814247 ; ibid 814253 (1959)

77) G.W. Holbrook, A.F. Gordon, O.R.Pierce, J. Am. Chem. Soc. 82825 (1960)

78) J.D. Park, J.R. Graves, J.R. Lacher, J. Org. Chem. 251628 (1960)

79) W.H. Knoth, D.D. Coffman, J. Am. Chem. Soc. 823873 (1960)
80) P. Tarrant, USP 2, 922, 823 (1960)

81) R.E. Putnam, J.E. Castle, J. Am. Chem. Soc. 83389 (1961)

82) P. Tarrant, R.W. Johnson, Jr., W.S. Brey, Jr., J. Org. Chem. 27602 (1962)

83) J.J. Drysdale, W.W. Gilbert, H.K. Sinclair, W.H. Sharkey, J. Am. Chem. Soc. 803672 (1958)

[84) W.R. Brasen, H.E. Halmquist, R.E. Benson, J. Am. Chem. Soc. 82995 (1960)

85) J.L. Anderson, USP 2, 743,303 (1956)

86) J.D. Roberts et al., J. Am. Chem. Soc. 75 4765 (1953); ibid. 78 2005, 4023 (1956); ibid 80 4088, 5840 (1958); ibid. 83, 871 (1961)

87) J.D. La Zerte, R.J. Koshar, J. Am. Chem. Soc. 77910 (1955)

88) H. Muramatsu, K. Inukai, J. Org. Chem. 27 1572 (1962); 村松, 犬飼, 工化 651992 (1962)

89) J.F. Harris, Jr., D.D. Coffman, J. Am. Chem. Soc. 841553 (1962)

90) E.R. Bissell, D.B. Fields, J. Org. Chem. 29 249 (1964)

91) D.C. England, J. Am. Chem. Soc. 832205 (1961)

92) D.A. Barr, R.N. Haszeldine, J. Chem. Soc. 1881 (1955); D.A. Barr, R.N. Haszeldine, C.J. Willis, Proc. Chem. Soc. 230 (1959)

93) D.A. Barr, R.N. Haszeldine, C.J. Willis, J. Chem. Soc. 1351 (1961)

94) C.E. Griffin, R.N. Haszeldine, J. Chem. Soc. 1398 (1960)

95) C.E. Griffin, R.N. Haszeldine, Proc. Chem. Soc. 369 (1959)

96) J.M. Birchall, A.J. Bloom, R.N. Haszeldine, C.J. Willis, Proc. Chem. Soc. 367 (1959)

97) D.A. Barr, R.N. Haszeldine, J. Chem. Soc. 1151 (1960)

98) D.C. England, M.A. Dietrich, R.V. Lindsey, Jr., J. Am. Chem. Soc. 826181 (1960)

99) P.D. Bartlett et. al., J. Am. Chem. Soc. 86 $616,622,628$ (1964) 